\title{
"Is There a Text in this Class?" The Conflict Between Textualism and Antitrust
}

\author{
DANIEL A. FARBER* \\ BRETT H. MCDONNELL**
}

\section{TABLE OF CONTENTS}

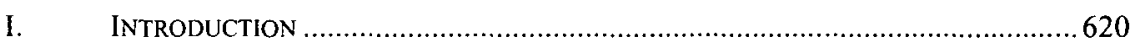

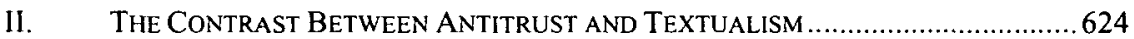

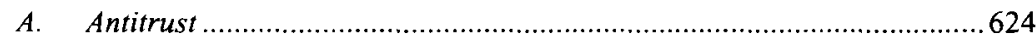

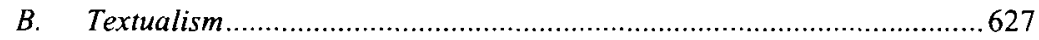

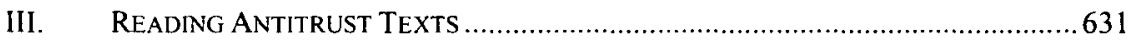

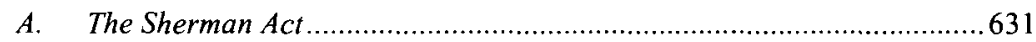

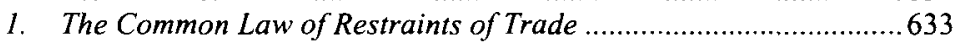

2. Textualist Interpretation of Common-law Terms ………………….....636

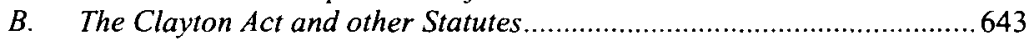

1. The Clayton Act, Mergers, and the Efficiency Defense......................644

2. The Robinson-Patman Act, Price Discrimination, and Predatory Pricing .................................................................... 647

3. The Federal Trade Commission Act and Congressional Delegation .............................................................654

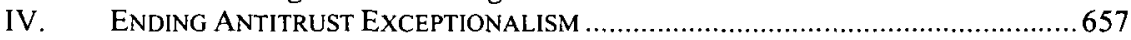

A. Beyond the Delegation Theory............................................................657

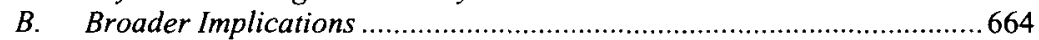

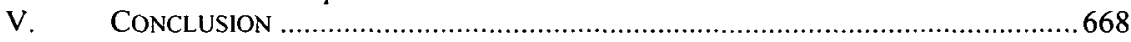

* Sho Sato Professor of Law, University of California at Berkeley.

** Associate Professor of Law, University of Minnesota. The authors would like to thank Dan Gifford, John Manning, Matt McCubbins, David McGowan, Dan Rodriguez, and Tom Sullivan for their helpful comments, along with workshop participants at San Diego. 
Every issue of law resolved by a federal judge involves interpretation of text-the text of a regulation, or of a statute, or of the Constitution. ${ }^{1}$

\section{INTRODUCTION}

Literary theorist Stanley Fish recounts the story of the student who, after taking a class from him, asked another teacher whether there was a text in that other class. ${ }^{2}$ The other teacher thought at first that the student was making a routine inquiry about textbook assignment, but it soon became clear that she had a more fundamental worry on her mind. What she was asking was whether, given Fish's emphasis on the creative role of the reader in interpretation, the literary text actually retained any meaning or relevance of its own. Or, as she put it, "I mean in this class do we believe in poems and things, or is it just us?"

Many students of antitrust law could be forgiven for asking a similar question. Antitrust cases generally discuss precedent and economic policy. They rarely include more than a passing citation to the statutory text. Discussions of antitrust often focus on economics, leaving many students with the feeling that they have mistakenly wandered into an econ class rather than a law class. Indeed, even two decades ago, Frank Easterbrook was able to announce with some satisfaction that the latest Supreme Court opinions "read like short treatises on microeconomic analysis." In antitrust, then, it seems that there are no statutory texts, just "us"-more specifically, contemporary judges and economists.

The reason, it would appear from the writings of scholars and judges, is that the statutory texts are essentially devoid of content. Or rather, they are merely an instruction to judges to use their best economic judgment. By using the common law term, "restraint of trade," we are told, the Sherman Act "invoked the common law itself, and not merely the static content that the common law had assigned to the term in 1890." In using this term, it is also said, the statute "refers not to a particular list of agreements, but to particular economic consequences, which may be produced by quite different sorts of agreements in varying

1. ANTONIn Scalia, A Matter of InTERPRetation: Federal Courts and the LAW 13 (1987).

2. Stanley Fish, Is There a TeXt IN THIS Class? The Authority of INTERPRETATIVE COMMUNITIES 305 (1980).

3. Frank H. Easterbrook, Foreword: The Court and the Economic System, 98 HARV. L. REV. 4, 57 (1984).

4. Business Electronics v. Sharp Electronics, 485 U.S. 717, 732 (1988). 
times and circumstances." No wonder that today antitrust often seems to be more about economics than about law.

What is remarkable is that this praise of judicial activism in antitrust comes from Justice Scalia, the foremost judicial advocate of textualism. As we will see, although textualists have sometimes been described as striving "with missionary zeal to narrow the focus of consideration to the statutory text and its 'plain meaning"", 6 this is hardly true in antitrust law. Other leading textualists share Justice Scalia's celebration of the text-free nature of antitrust law.? For example, Judge Easterbrook has said that the Sherman Act "does not contain a program; it is a blank check." statutory interpretation, this casual disregard for textual guidance is not at all the way textualists normally approach statutes:

[T] he new textualism holds that the only object of statutory interpretation is to determine the meaning of the text and that the only legitimate sources for this inquiry are text-based or -linked sources. Thus, the meaning an ordinary speaker of the English language would draw from the statutory text is the alpha and the omega of statutory interpretation. ${ }^{9}$

5. Id. at 731 .

6. David L. Shapiro, Continuity and Change in Statutory Interpretation, 67 N.Y.U. L. REV. 921, 922 (1992). Admittedly, this may be an oversimplification of textualism. A more nuanced version is that textualists believe "that at the very least, a substantial part of the meaning of a statute is ordinarily ascertainable from a close reading of the statutory language, and from 'commonsensical' inferences deriving from the canons of construction." Lawrence M. Solan, Learning Our Limits: The Decline of Textualism in Statutory Cases, 1997 WIS. L. REv. 235, 243.

7. See text accompanying infra notes 153-57.

8. Frank Easterbrook, Workable Antitrust Policy, 84 MICH. L. REv. 1696, 1701 (1986). The title of this article is itself revealing: note that Easterbrook speaks of workable antitrust policy, not workable antitrust law. Contrast the title of one of the relatively rare articles arguing for greater attention to the antitrust statutes, Thomas Arthur, Workable Antitrust Law: The Statutory Approach to Antitrust, 62 TuL. L. REv. 1163 (1988).

9. William EsKridge, Philip Frickey, and Elizabeth GarretT, Legislation AND STATUTORY INTERPRETATION 228 (2000). This does not mean that textualists limit themselves to the interpretation which might be favored by the "person on the street." Rather, these authors explain, textualists look at some sources of context that might not be familiar to the "ordinary speaker of English": dictionaries (especially those dating from the period of enactment), interpretations of similar provisions in related statutes and their judicial interpretations, and other provision of the statute itself. Id. Although the authors are not themselves textualists, we believe that these statements are fair descriptions of textualist methodology. 
To be sure, Scalia and other textualists have offered reasons for considering antitrust laws as exceptions to the normal regime of statutory interpretation. Yet, their arguments are remarkably cursory, given how radically their antitrust jurisprudence departs from their usual approach to statutory interpretation. We believe that this antitrust exceptionalism is unwarranted. The antitrust laws differ at most only in degree from other statutes, and perhaps not very much even in degree. Thus, our claim is that textualists like Scalia and Easterbrook cannot both have their cake and eat it: they should either rethink their textualism or seriously consider jettisoning their approach to antitrust law.

Antitrust lawyers typically respond to this claim by arguing that antitrust law is good sensible policy-good not only in terms of its evenhanded pursuit of economic welfare but also in its predictability and judicial administrability. Not everyone would agree with this assessment of current law, but more fundamentally, this argument misses the basic premise of textualism. The whole point of textualism is that statutory interpretation should eschew such policy analysis. Court are not to make whatever social policy they think best; they are to derive doctrine from careful attention to the words of the laws that Congress has actually enacted. However admirable antitrust doctrine may be as a matter of social policy, it simply cannot be squared with this philosophy.

Modern antitrust doctrine is incompatible with textualism in another regard. As Eskridge and Ferejohn have observed, the Sherman Act has functioned as a kind of superstatute. That is, like a constitutional provision, it has been treated as establishing a broad social norm, and it has "generated a presumption that other regulatory schemes give way to its pro-competition policy." 10 For a textualist, however, a statute is not the embodiment of some transcendent norm; it is a set of words that courts are required to implement according to their terms. Nor does the Constitution provide any distinction between lesser and greater statutes: they are each passed through the process of bicameralism and presentment, and they are each "the Supreme Law of the Land."

We can hardly improve on Eskridge and Ferejohn's description of the tension between antitrust and the more textualist approaches currently in favor:

10. William N. Eskridge, Jr. \& John Ferejohn, Superstatutes: The New American Constitutionalism 17 (Mar. 13, 2004) (on file with the authors.) As will be clear from the text, we agree with Eskridge and Ferejohn's description of how courts implement the Sherman Act today. We contend, however, that this approach is in direct conflict with the strictures of textualism. Since Eskridge and Ferejohn are not textualists, they would presumably be unfazed by this observation. 
The interpretative history of the Sherman Act provides a classic illustration of the gravitational force a super-statute exercises on the law ... To begin with, a superstatute will generally be applied in a purposive rather than simple text-bounded or originalist way. It will generate a dynamic common law implementing its great principle and adapting the statute to meet the challenges posed to that principle by a complex society.... Although the Burger and Rehnquist Courts have emphasized plain meanings and common law backgrounds in statutory cases more than their predecessors, they have nonetheless construed the Sherman Act in the purposive, evolutive way the New Deal and Warren Courts did. ${ }^{11}$

As Eskridge and Frickey go on to point out, the "boldest statement of this methodology came from archtextualists Antonin Scalia." 12 In this Article, we attempt to call textualists to account for this inconsistency.

Our analysis proceeds as follows. In Part II, we provide brief sketches of modern antitrust analysis and textualist theory, in order to highlight the contrast. We try to steer clear from caricaturing textualism as a simple-minded "plain meaning" doctrine. While we cannot do justice to all of the nuances of textualism or all of the varying formulations of the theory, we will use statements by some of its leading, most sophisticated advocates to create a sketch of their methodology.

In Part III, we apply the standard tools of textualist interpretation to the antitrust statutes. For the conscientious textualist, the statutory texts have considerably more specific meaning than the conventional wisdom would suggest. We would expect the students in our Legislation classes to come up with these arguments if they were given the statutory texts; it is remarkable that even textualist judges have failed to take a hard look at the language of the statutes. (Neither have non-textualist judges, but that seems more understandable. $)^{13}$ We also suggest that textualists should defer more to FTC interpretations than current courts do.

11. William N. Eskridge, Jr. \& John Ferejohn, Super-Statutes, 50 DukE L.J. 1215, 1234 (2001).

12. Id.

13. This is not to say that text has played no role at all in antitrust law. For example, the Court has adverted to the word "combination" in determining which multilateral conduct is covered by the statute. See United States v. Parke, Davis \& Co., 362 U.S. 29, 44-45 (1960). Perma Life Mufflers, Inc. v. International Parts Corp., 392 U.S. 134, 142 (1968); see also Copperweld Corp. v. Independence Tube Corp. 467 U.S. $752,768-71$ (1984) (calling attention to the statutory term "conspiracy" to explain why a parent and wholly-owned subsidiary could not violate section 1 of the Sherman Act). A more recent example is Spectrum Sports, Inc. v. McQuillan, 506 U.S. 447, 454 (1993) (focusing on statutory reference to "commerce"). Notably, each of these examples involves threshold coverage rather than the substance of competition policy. 
In Part IV, we argue for an end to antitrust exceptionalism. The primary textualist argument for exceptionalism is that the antitrust laws were a delegation of law-making power to the courts, quite unlike the usual statute where Congress itself establishes the operative legal rules. This delegation argument, however, turns out to be nothing more than a restatement of the claim that the antitrust statutes lack any ascertainable content of their own, and that claim is untenable. For dynamic interpreters like Eskridge and Ferejohn, the Sherman Act may embody a quasi-constitutional norm that transcends the statutory text, but such statutory transcendentalism is the exact opposite of textualism.

We conclude the paper with some speculations about the implications of rejecting the textualist dogma of antitrust exceptionalism. Most obviously, textualists should reconsider their approach to antitrust. Even non-textualists may come away from the analysis feeling that the statutory texts have received unduly short shrift from the modern court. Those who approve of modern antitrust doctrine, on the other hand, should find textualism less appealing because of this incompatibility, and they may be drawn to more dynamic theories of statutory interpretation such as that espoused by Eskridge and Ferejohn

\section{The CONTRast BetweEn ANTITRUST AND TeXTUalism}

Some of our readers are probably familiar with antitrust but not with theories of statutory interpretation; others will have the reverse background; and for some, both will be novel territory. We begin, therefore, with overviews of the two fields.

\section{A. Antitrust}

Antitrust law today is widely understood to be a variant of the common law, but a variant peculiarly focused on explicit economic analysis. Presented with a business practice, courts will examine that practice to determine whether it advances or impedes economic efficiency. If it advances efficiency the court will find no antitrust liability. Normally the analysis is done on a case-by-case basis under the rule of reason. For a very few practices, the Court has decided that those practices are likely enough to reduce efficiency that the Court has held them per se violations of the antitrust law. The analysis proceeds via a review of the relevant case law and an inquiry into the economic effects of the practice, often guided by analysis done by economists. The statutory language gets only a momentary mention, adding little or nothing to the discussion, particularly in cases that invoke only the Sherman Act.

To get a feel for how this analysis proceeds, consider State Oil Co. v. 
Khan ${ }^{14}$ Khan dealt with maximum vertical resale price fixing. State Oil had entered into an agreement with Khan where Khan would obtain gas from State Oil to sell at Khan's gas station. If Khan charged a price above State Oil's suggested retail price, Khan had to rebate the excess to State Oil. Thus, the contract made it senseless for Khan to charge more than the suggested retail price. ${ }^{15}$ The Court had previously held that such maximum vertical price fixing was a per se violation of the Sherman Act in Albrecht v. Herald Co ${ }^{16}$ Khan overruled Albrecht and held that the rule of reason applies in such a situation.

Justice O'Connor begins the analysis in her opinion for a unanimous Court as follows: "Although the Sherman Act, by its terms, prohibits every agreement 'in restraint of trade,' this Court has long recognized that Congress intended to outlaw only unreasonable restraints." ${ }^{17}$ That's it for the statutory text. The rest of the analysis is all study of previous cases and economics, with nary a mention of the text.

O'Connor begins by explaining the difference between the rule of reason and per se rules, noting "we have expressed reluctance to adopt per se rules with regard to 'restraints imposed in the context of business relationships where the economic impact of certain practices is not immediately obvious." "'18 She then starts to trace the evolution of relevant precedents. The Court early on held that minimum resale prices were per se invalid in Dr. Miles Medical Co. v. John D. Park \& Sons $\mathrm{Co}^{19}$ The Court more broadly held per se illegal combinations and agreements limiting resale prices in United States v. Socony-Vacuum Oil Co. ${ }^{20}$ and Kiefer-Stewart Co. v. Joseph E. Seagram \& Sons, Inc. ${ }^{21}$ The Court considered non-price restrictions by suppliers on dealers in White Motor Co. v. United States 22 and decided it did not understand these enough to declare them per se illegal. Four years later it discovered it had acquired adequate understanding and declared such vertical nonprice restrictions per se illegal in United States v. Arnold, Schwinn \&

14. 522 U.S. 3 (1997).

15. See id. at 7-8.

16. 390 U.S. 145 (1968).

17. Id at 10. This is in the context of vertical agreements. Horizontal price agreements remain per se illegal.

18. Id.

19. 220 U.S. $373(1911)$.

20. 310 U.S. 150 (1940).

21. 340 U.S. 211 (1951).

22. 372 U.S. 253 (1963). 
$\mathrm{Co}^{23}$ The next year the Court made clear that maximum resale prices were per se illegal in Albrecht.

Not long after that, intellectual fashion changed. Chicago economics was in, and legal analysts were more inclined to understand various business practices as promoting efficiency rather than collusion. The Court reflected the shift. In 1977 it overruled Schwinn in Continental T $V$., Inc. v. GTE Sylvania Inc. ${ }^{24}$ The Continental Court noted how much scholarly opinion had criticized Schwinn. Several later cases hinted that Albrecht was on shaky ground. ${ }^{25}$

Having reviewed this judicial history, the Khan Court turns to its economic analysis. It states that "the primary purpose of the antitrust laws is to protect interbrand competition" and that "condemnation of practices resulting in lower prices to consumers is "especially costly.",26 Citing Judge Posner's opinion in the lower court, it notes that unless the supplier is a monopsonist it cannot squeeze its dealer's profits too much, or they will switch to other suppliers, but suppliers might set a maximum resale price to prevent their dealers from exploiting a monopoly position. ${ }^{27}$

The Court then shoots down some arguments from Albrecht. Although resale price fixing might indeed limit dealer freedom, banning such price fixing would lead some suppliers to distribute their own goods, thus eliminating the dealers altogether. ${ }^{28}$ The Albrecht Court had also worried that maximum prices could be so low that dealers would not offer desired services. Justice O'Connor replies that this would go against the supplier's own interests. ${ }^{29}$ To the concern that price fixing squeeze out small dealers, the Court responds that this is not clearly so, and that anyway limiting inefficient dealers is no bad thing. ${ }^{30}$ The Court also acknowledges that maximum price limits can be used to disguise minimum price limits (which remain per se illegal), but Justice O'Connor argues that instances of this can be caught through the rule of reason. ${ }^{31}$ The Court concludes that the dangers of maximum vertical price fixing

23. 388 U.S. 365 (1967). The rule of reason still applied where goods were consigned rather than sold.

24. 433 U.S. 36 (1977).

25. See Khan, 522 U.S. at 14 (citing Arizona v. Maricopa County Medical Soc, 457 U.S. 332, 348 n. 18 (1982); 324 Liquor Corp. v. Dujfy, 479 U.S. 335, 342-42 (1987); and $A R C O, 495$ U.S. 328, 335 n.5 (1990)).

26. Id. at 15 .

27. See id. at 15-16.

28. See id. at 16. Economists revel in pointing out unintended consequences of state interventions.

29. See id. at 17.

30. See id.

31. See id. 
are speculative enough that they do not justify a per se rule. ${ }^{32}$

The final obstacle to overruling Albrecht that the Court had to dodge was stare decisis. Justice O'Connor acknowledges that stare decisis is an important policy, and particularly strong in statutory interpretation and cases involving property and contract rights. ${ }^{33}$ But stare decisis "has less force with respect to the Sherman Act in light of the accepted view that Congress 'expected the courts to give shape to the statute's broad mandate by drawing on common law tradition.",34 So not only does the Court feel free to ignore the statute's language, it feels relatively free to ignore its prior decisions as well. Voila, stare decisis no longer blocks the desired outcome.

Khan is in no way an aberrational case. We have used it to illustrate how the Court approaches the antitrust statutes precisely because it is quite run of the mill. That is how the Court goes about statutory interpretation in antitrust. Or perhaps it would be more accurate to say that statutory interpretation, in the sense of trying to give meaning to the words of the statute, does not have much to do with antitrust law.

\section{B. Textualism}

Having taken a quick look at the approach used by the modern court in antitrust cases, we now present an overview of textualist theory. Merely to juxtapose textualist theory with antitrust law is to make clear the tension between the two.

The central premise of textualism is that statutory interpretation is about texts, not about policymaking or legislative purpose. As Justice Scalia explains,

To be a textualist in good standing, one need not be too dull to perceive the broader social purposes that a statute is designed, or could be designed, to serve; or too hidebound to realize that new times require new laws. One need only hold the belief that judges have no authority to pursue those broader purposes or write those new laws. ${ }^{35}$

It is primarily for this reason that Scalia criticizes the concept of legislative intent. He does have a secondary concern: what he calls the "theoretical" threat that judges will implement legislative desires that did

32. See id. at 18 .

33. See id. at $\mathbf{2 0 .}$

34. Id.

35. Scalia, supra note 1 , at 24 . 
not make it into the actual statute. ${ }^{36}$ But his emphasis is elsewhere: he views the important "practical threat" to be that judges will implement their own desires; "under the guise or even the self-delusion of pursuing unexpressed legislative intents, common-law judges will in fact pursue their own objectives and desires, extending their lawmaking proclivities from the common law to the statutory field." ${ }^{37}$ (Some might argue that economic theory is so clear and so well settled that it leaves little room for judicial discretion, but even were this to be true-and we are inclined to doubt $\mathrm{it}^{38}$-economics is only one of several approaches that the Court could have chosen, and the decision to choose economic efficiency as the standard was itself an exercise in lawmaking, at least in textualist terms. Moreover, if economics can adequately constrain non-textualist judges in the area of antitrust, why not in other areas as well?) Indeed, according to some textualists, searching for legislative intent or purpose is a snipe hunt: "Because legislatures comprise many members, they do not have 'intents' or 'designs,' hidden yet discoverable." ${ }^{39}$ For this reason, courts should be reluctant to expand statutes to new domains "unless the statute plainly hands courts the power to create and revise a form of common law. ..."40

How, then, should textualists read statutes? Not simply by use of a dictionary. Despite the tendency of critics to equate textualism with the plain meaning rule, this is an oversimplification. Textualism does not equal literalism, because textualists have some appreciation of the importance of context. As Judge Easterbrook says, "[1] anguage takes meaning from its linguistic context, but historical and governmental contexts matter too." ${ }^{\prime 41}$ Justice Scalia's effort to articulate textualist methodology is instructive. According to Justice Scalia, the proper method has two stages: "first, find the ordinary meaning of the language in its textual context; and second, using established canons of statutory construction, ask whether there is any clear indication that some permissible meaning

36. Manning places more emphasis on this issue than Scalia. See John Manning, Textualism as a Nondelegation Doctrine, 97 CoLUM. L. REV. 673, 694-95 (1997).

37. Id. at 17-18.

38. See George J. Stigler, The Politics of Political Economists, in ESSAYS IN THE HISTORY OF ECONOMICS 51, 63 (1965) ("The apparatus of economics is very flexible: without breaking the rules of the profession. . . a sufficiently clever person can reach any conclusion he wishes on any real problem. ... In general there is no position . . which cannot be reached by a competent use of respectable economic theory."). See also infra notes 172-74 and accompanying text.

39. Frank Easterbrook, Statutes ' Domains, 50 U. CHI. L. REv. 533, 547 (1983).

40. Id. at 544 .

41. Frank H. Easterbrook, The Case of the Speluncean Explorers: Revisisted, 112 HARV. L. REV. 1913, 1913 (1999). 
other than the ordinary one applies."42 It is wrong, Justice Scalia emphasizes, for the Court to avoid the ordinary meaning, merely because the ordinary meaning "does not fit the Court's conception of what Congress must have had in mind," as opposed to being "irrational, or inconsistent with other parts of the statute." 43 Thus, ordinary meaning figures heavily in textualism. ${ }^{44}$ But contemporary textualism, at least in theory, is much more attentive to legal context than a more simplistic "plain meaning" approach. ${ }^{45}$

For present purposes, a particularly important aspect of textualism is its respect for the established meaning of legal terms of art, when used in statutes. Textualists "give effect to terms of art that have acquired specialized connotations through use over time by specialized communities"- and for "statutes, the lawyer's lexicon . . . has particular relevance." 46 Thus, textualists "often rely on extrinsic sources, such as judicial decisions and legal treatises, to determine the specific meaning of codified terms of art.",47

Textualists also avoid literalism by relying on canons of interpretation. Or, to put it more discursively, "textualists unflichingly rely on legal conventions that instruct courts, in recurrent circumstances, to supplement the bare text with established qualifications designed to advance certain substantive policies." ${ }^{248}$ Of these conventions, perhaps the best established is the rule of lenity, which is said to be "almost as old as the common law itself." 49 This canon has a number of roots: the desire to limit

42. Chisom v. Romer, 501 U.S. 380, 404 (1991) (Scalia, J. dissenting).

43. Id. at 417 .

44. As Phil Frickey points out, this reference to "ordinary meaning" is "deeply ambiguous," because it fails to specify how much of the surrounding context is accessible to that reader. Philip P. Frickey, Faithful Interpretation, 73 WASH. U. L.Q. 1085, 1090 (1995). Textualism's uniqueness begins to blur to the extent the reader is supposed to be "faithful to the many broader concerns wrapped up in the established practices of the legal interpretative community." Id. at 1091.

45. Some commentators believe that the textualists' actual performance is more literal-minded and simplistic than this description of their theory might suggest. See Melvin Eisenberg, Strict Textualism, 20 LoYoLA L.A. L. REV. 13 (1995); Richard Pierce, The Supreme Court's New Hyptertextualism: An Invitation to Cacophony and Incoherence in the Administrative State, 95 Colum. L. REv. 749 (1995). For a more sympathetic but ultimately critical perspective, see William Eskridge, The New Textualism, 37 UCLA L. REV. 621 (1990).

46. John Manning, The Absurdity Doctrine, 116 HARV. L. REV. 2387, 2464 (2003).

47. Manning, Nondelegation Doctrine, supra note 36, at 695.

48. Id. at 2466 .

49. Scalia, supra note 1 , at 29. Scalia expresses a notable lack of enthusiasm for 
prosecutorial discretion, the need for fair notice to defendants, a libertarian presumption against extending government restrictions, and the presumption that "it is the legislative, not the judicial function to define crimes." 50

Some other aspects of textualist analysis are also worth mentioning. A textual analysis (whether conducted by a "textualist" or not) often looks at the overall structure of the statute as well as its specific terminology. ${ }^{51}$ Textualists and others agree that statutes should be interpreted where possible to be coherent, so that the statute as a whole makes sense and the same words mean the same things wherever they are used. $^{52}$ Likewise, statutes should be construed to give each provision a distinctive meaning, rather than making some of them redundant (the "surplusage" rule)..$^{53}$

Finally, where multiple statutes are potentially applicable, the more specific statute controls the more general. ${ }^{54}$ (If anything, this seems to be the direct opposite of the concept of superstatutes, where broad general statutes are thought to override more specific ones.) Similarly, later statutes may limit the inferences that would otherwise be drawn from an earlier statute. As Justice Scalia explains:

Repeal by implication of an express statutory text is one thing .... But repeal by implication of a legal disposition implied by a statutory text is something else. The courts frequently find Congress to have done this-whenever, in fact, they interpret a statutory text in the light of surrounding textshappen to have been enacted. This classical judicial task of reconciling many laws enacted over time, and getting them to "make sense" in combination, necessarily assumes that the implications of a statute may be altered by the implications of a later statute. ${ }^{55}$

An apt example of textualist methodology is provided by Justice Scalia's dissent in Babbitt v. Sweet Home Chapter of Communities for a Great Oregon. ${ }^{56}$ The Endangered Species Act makes it unlawful to "take" an endangered species, and another section defines take to include "harm." The question before the Court was whether destroying a species's habitat violated the statute. Agreeing with the agency in charge of implementing the statute, the majority held that habitat destruction is covered by the statute. Justice Scalia disagreed. He found that the statute unambiguously

the canons, but finds this one the most acceptable.

50. ESKRIDGE ET AL., supra note 9, at 363.

51. Id. at 269 .

52. Id. at $263-65$.

53. Id. at 267 .

54. Id. at 275 .

55. United States v. Fausto, 484 U.S. 439, 453 (1988).

56. 515 U.S. 687 (1995). 
excluded habitat destruction. After surveying dictionaries, cases, and Blackstone, Scalia concluded that the word "take" was an ancient legal term, meaning to reduce an animal to human control through capture or killing. Finding nothing else in the statute to contradict this established usage, he concluded that the statute was unambiguous. In addition, he pointed out, the majority's interpretation made one subsection duplicative, violating the surplusage rule. ${ }^{57}$

In Sweet Home, Justice Scalia chided the majority for "the vice of 'simplistically ... assum[ing] that whatever furthers the statute's primary purpose must be the law." 88 For "[d]eduction from the broad purpose of a statute begs the question if it is used to decide by what means (and hence to what length) Congress pursued that purpose; to get the right answer to that question there is no substitute for the hard job (or in this case, the quite simple one) of reading the whole text." 59

Bearing that admonition in mind, we turn to the antitrust statutes themselves. The question we ask ourselves is essentially the following: putting aside all of the later rulings that may or may not have been true to the statutory text, how would a textualist have determined the meaning of the antitrust statutes?

\section{READING ANTITRUST TEXTS}

This section may be considered something of a thought experiment. We ask the reader to picture a judge such as Scalia faced for the first time with recently enacted antitrust statutes, before those statutes had become encrusted with precedent. How would such a textualist judge have interpreted the statutes? We start with the Sherman Act, and then move to later acts. Courts have tended to confound these different acts, treating the Sherman Act as setting general antitrust policy and bending the later acts to that policy ("superstatute"-style), despite the greater specificity of the Clayton and Robinson-Patman Acts and the stricter limits that they impose on firms within the areas that they apply.

\section{A. The Sherman Act}

Judge Easterbrook tells us that the "fundamental premise of antitrust is

57. Id. at 714-24.

58. Id. at 726 (emphasis in original).

59. Id. (emphasis in original). 
the ability of competitive markets to drive firms toward efficiency." $" 60$ Thus, he continues, the "entire corpus of antitrust doctrine is based on the belief that markets do better than judges or regulators in rewarding practices that create economic benefit and penalizing others." ${ }^{\prime 61}$ But since nothing like this language appears in the Sherman Act, a textualist might wonder how these fundamental premises are derived. Where does the focus on economic efficiency come from, textually speaking?

The answer, according to Justice Scalia, is that "[ $t]$ he term 'restraint of trade' in the statute, like the term at common law, refers not to a particular list of agreements, but to particular economic consequences, which may be produced by quite different sorts of agreements in varying times and circumstances." 62 "He also observes that even at the time the Sherman Act was passed, courts recognized that the common law was evolving. ${ }^{63}$ Thus, the touchstone even then was economic welfare; the specific holdings of the cases were merely efforts to approximate that outcome.

Essentially, Scalia's theory is that the common law involved a standard rather than a rule, and that this standard was based on something akin to the efficiency goal that now animates antitrust law. Both parts of this assertion are at best only partially correct. In reality, the common law had important rule-like features, and common law courts then (and now) were not focused on the dangers of market dominance. Although a fuller investigation of Nineteenth Century legal history would be needed to definitively settle the questions, the indications are that it would be more accurate to say that the common law's goals were fairness and economic independence. In particular, the common law was frequently indifferent to whether the restraint of trade involved any significant portion of the market. Indeed, even today, the common law doctrine of restraints on trade has some concerns that are far removed from market power.

Our analysis of section 1 of the Sherman Act proceeds in two stages. First, we provide a description of the common law as it existed in 1890. Second, we ask how dynamic a view textualists should take of the statutory term "restraint of trade". The best textualist reading of the Sherman Act is probably a static one, incorporating the common law of restraints on trade as it existed in 1890. But even if a dynamic understanding is adopted, a textualist should probably look for guidance to the evolving common law of contractual restraints, rather developing an entirely

60. Frank Easterbrook, The Limits of Antitrust, 63 TEX. L. REV. 1, 24 (1984).

61. Id.

62. Business Electronics, 485 U.S. at 731.

63. Id. at 731-32. 
independent body of federal law. In short, even under a relatively dynamic version of textualism, the source of guidance in antitrust cases should be the Restatement (Second) of Contracts rather than a microeconomics text.

Lest we be accused of maliciously pushing textualists into an absurd position, we will show that our reading of the statute would have been a plausible policy choice in 1890 . Under our proposed textualist reading, the statute would still have been a significant step toward addressing abusive business conduct.

\section{The Common Law of Restraints of Trade}

Before we immerse ourselves in nineteenth century law, it is useful to begin by leaping a few decades later, to the First Restatement of Contracts, which has the advantage of providing a cogent summery of the law. Here is what the First Restatement has to say about unreasonable restraints on trade:

A restraint of trade is unreasonable, in the absence of statutory authorization or dominant social or economic justification, if it

(a) is greater than is required for the protection of the person for whose benefit the restraint is imposed, or

(b) imposes undue hardship upon the person restricted, or

(c) tends to create, or has for its purpose to create, a monopoly, or to control prices or to limit production artificially, or

(d) unreasonably restricts the alienation or use of anything that is a subject of property, or

(e) is based on a promise to refrain from competition and is not ancillary either to a contract for the transfer of good-will or other subject of property or to an existing employment or contract of employment. ${ }^{64}$

What immediately stands out is that only one of the five standards (subsection c) speaks in terms of price, output, or market power. A look at the comments reveals that even subsection $c$ was applied with an eye to non-efficiency concerns. Consider illustration 16:

64. Restatement (First) of Contracts, $\S 515$ (1932). The First Restatement has been described as an "authoritative and comprehensive" description of the law on this point. Milton Handler \& Daniel Lazaroff, Restraint of Trade and the Restatement (Second) of Contracts, 57 N.Y.U. L. REv. 669, 670 (1982). 
A, B, C and D, who are farmers, bargain together with other farmers that they will sell all their farm products to a co-operative association for purposes of resale. The purpose of the bargain is to secure better facilities for marketing their products and thereby to avoid sale of them at a sacrifice. The agreement is legal, though its anticipated effect is to maintain or raise prices, since the economic position of individual farmers is such as to require co-operative bargaining.

Other subsections stray further from efficiency. Perhaps subsection (e) might be at least consistent with economic efficiency, if we assume that efficiency justifies restricting non-compete agreements to the four narrow categories listed by the Restatement. (Note, however, that both of these rules are subject to the opening proviso of the section, which allows otherwise unreasonable restraints in the presence of "statutory authorization or dominant social or economic justification.") The other three categories have much more to do with fairness than with efficiency, at least in their modern applications. For example, subsection (d) adopts the common law rule against restraints on alienation-that is, a ban on vertical restraints of the kind approved by the Court in Khan. Not surprisingly, whatever utility it may have had in helping to break up the feudal system in England, the modern common law rule against unreasonable restraints on trade has been sharply criticized on efficiency grounds. ${ }^{65}$

Much has been written about the common law as it existed in $1890 .^{66}$ We will not attempt to survey the cases, or even to offer the equivalent of a Restatement. ${ }^{67}$ There are, however, several important features of the common law that were clearly established in the late Nineteenth Century and are worthy of notice.

First, the rule against restraints on trade was not an all-purpose tool to promote competition. It did little or nothing to address mergers, which were considered to be a matter for corporate law to address. ${ }^{68}$ Unquestionably, particularly in the later part of the Nineteenth Century, there was increasing concern about the effects of massive mergers. But the primary legal tools used to control these mergers stemmed from corporation law,

65. See Maureen Callahan, Post-Employment Restraint Agreements: A Reassessment, 52 U. CHI. L. REV. 703 (1985).

66. For a thorough survey, see Philip Areeda \& Herbert Hovenkamp, 1 ANTITRUST LAW (1997) [hereinafter AREEDA, 1 ANTITRUST LAW].

67. Since it would cover the law prior to the Restatement (First), presumably it would have to be called the Restatement (Zero).

68. Id. para. 104 , at $67,70-73$. In another work, one of the treatise authors places these decisions in the broader context of Nineteenth Century legal thought and its relationship to developments in economics. See HERBERT HOVENKAMP, ENTERPRISE AND AMERICAN LAW, 1836-1937, at 241-95 (1991). 
not from the common law rule against restraints on trade. ${ }^{69}$ The language of the Sherman Act, of course, invokes the contracts doctrine by making "unreasonable restraint of trade" the operative standard.

Second, the lines drawn in common law doctrine were rather different from modern antitrust doctrine. As the leading modern antitrust treatise explains, the contract doctrine was mostly concerned with "contract and freedom from coercion" rather than "price-cost relationships," and "it made little distinction between 'horizontal' and 'vertical' arrangements in restraint of trade." 70 On the other hand, the common law did sharply distinguish between restraints involving "necessities" and other restraints. Contracts restraining trades in necessities were "treated more harshly than those involving goods about which buyers were thought to have more discretion"; and this "rule of heightened scrutiny applied both to classical contracts in restraint of trade and to price-fixing agreements."

Third, the rule of reason did not apply to all categories of restraints. It did apply to non-compete covenants that were ancillary to the sale of property or a business, or to the employment relationship. But there was little precedent applying the ancillary restraint concept outside of these categories. ${ }^{72}$ On the other hand, group boycotts were subject to virtually per se condemnation, on the ground that they were coercive. ${ }^{73}$

Clearly, the common law of 1890 only modestly resembled our modern law of antitrust. ${ }^{74}$ Indeed, a comparison with the First Restatement shows that even forty years after the Sherman Act, the common law still significantly diverged from modern antitrust doctrine. Under these

69. AREEDA, 1 ANTITRUST LAW, supra note 66, para. 102.

70. Id. para. 104 at 66. See also id. at 77 ("By and large, common law decisions treated contracts in restraint of trade involving horizontal competitors exactly as they treated those that did not.").

71. Id. at para. $104 \mathrm{c}$, at 85 .

72. Id. at para. $104 d$, at $90-92$.

73. Id. at para. $104 \mathrm{a}$, at 66 . Historic interpretation of the common law is made more complicated by the fact that, in the decade before the Sherman Act, some state courts were becoming more lenient in their treatment of restraints on trade, primarily in their review of ancillary restraints but also to some extent with nonancillary restraints, and courts did not always sharply distinguish the two. See James May, Antitrust in the Formative Era: Political and Economic Theory in Constitutional and Antitrust Analysis, 1880-1918, 50 OHо ST. L.J. 257, 311-31 (1989); see also HYLTON, infra note 74. In the event that textualists decide to take seriously the Nineteenth Century common law as the basis for interpreting the Sherman Act, a more detailed historical inquiry will no doubt be in order.

74. In our view, it is an oversimplification to collapse the common law doctrine into a cost-benefit test, as suggested in KEITH HYLTON, ANTITRUST LAW: ECONOMIC THEORY AND COMMON LAW EvOLUTION 34 (2003). 
circumstances, what should a textualist make of the use of the common law terminology in the Sherman Act?

\section{Textualist Interpretation of Common-law Terms}

As discussed in our earlier description of textualism, textualists give legal terms of art their technical meaning, not their everyday meaning, when they are found in statutes. The hard question for the textualist is not whether to interpret section 1 on the basis of the common law of contractual restraints. Instead, the hard textualist question is whether to view the term as embodying the common law at the time of enactment, or the common law of contracts as it evolved afterwards.

There is a substantial argument for the static view, molding the statute to the contours of the common law of 1890 . Indeed, that view was endorsed by four Justices not long after the passage of the statute, with the notable support of Justice Holmes. Holmes correctly observed that mergers were not covered by the existing common law, from which he concluded that they were not covered by the statute either. ${ }^{75}$ Indeed, Holmes's dissent a century ago in Northern Securities Co. v. United States $^{76}$ sounds remarkably like an exercise in modern-day textualism.

Holmes began by criticizing the lower court for its excessively policyoriented approach:

The court below argued as if maintaining competition were the expressed object of the act. The act says nothing about competition. I stick to the exact words used. The words hit two classes of cases, and only two,- - contracts in restraint of trade and combinations or conspiracies in restraint of trade,- and we have to consider what these respectively are. ${ }^{77}$

Holmes then observed that "[c]ontracts in restraint of trade are dealt with and defined by the common law."78 A merger did not meet the definition, because restraints on trade were defined as "contracts with a stranger to the contractor's business ..., which wholly or partially restrict the freedom of the contractor in carrying on that business as otherwise he would."79 Similarly, a combination in restraint of trade was an effort "to keep strangers to the agreement out of the business." ${ }^{80}$ Neither term plausibly covered the case at hand, for the merger merely combined the two existing businesses, containing no restrictions on freedom of action

75. See AREEDA, l ANTITRUSt LAW, supra note 66, at 70, para. 104.

76. 193 U.S. 197 (1904).

77. 193 U.S. at $403-04$.

78. Id. at 404

79. Id.

80. Id. 
and involving no effort to coerce third parties.

Holmes also argued that his interpretation of the statute was reinforced by two canons of interpretation. The first was the rule of lenity, for "all agree that before a statute is to be taken to punish that which always has been lawful, it must express its intent in clear words." ${ }^{81}$ Second was the canon of avoiding constitutional doubts, for under the constitutional doctrine of the time, there was a substantial argument that control of mergers exceeded Congress's power to regulate interstate commerce. In language somewhat reminiscent of the Court's more recent federalism forays, Holmes argued that the indirect effect of mergers on commerce was not enough to justify regulation. Allowing federal regulation based on such indirect effects, he maintained, would leave no stopping point for the commerce power. "Commerce depends upon population," wrote Holmes, "but Congress could not, on that ground, regulate marriage and divorce." $" 82$

A textualist would not necessarily have to be as rigid in interpreting the common law terms as Holmes. ${ }^{83}$ Textualists also sometimes use a more dynamic approach, taking into account the evolution of the common law in the state courts after the federal statute is enacted. But even when a statute does not adopt a static view of the common law, textualists normally do not regard this as an invitation to impose their own policy preferences. Rather, they stick close to the common law as it has evolved in the states.

Justice Thomas's opinion in Consolidated Rail Corp. v. Gottshall ${ }^{84}$ is illustrative of the cautiously dynamic approach that textualists use in this situation. The issue was whether a railroad employee, under a statute (the FELA) incorporating aspects of the common law of torts, was entitled to receive compensation for the infliction of emotional distress. The lower court had adopted a broad rule of recovery, on the theory that this would best further the remedial purposes of the statute. Justice Thomas was critical:

81. Id. at 402 .

82. Id. at 402 . He added: "If the act before us is to be carried out according to what seems to me the logic of the argument for the government ...., I can see no part of the conduct of life with which, on similar principles, Congress might not interfere." Id. at 402-03. Shades of Lopez!

83. Although some might be. See Smith v. Wade, 461 U.S. 30, 56 (Rehnquist, J., dissenting) (arguing that common law as of 1871 should apply in interpreting a section 1983 claim).

84. 512 U.S. 532 (1994). 
By treating the common-law tests as mere arbitrary restrictions to be disregarded if they stand in the way of recovery on "meritorious" FELA claims, the Third Circuit put the cart before the horse: The common law must inform the availability of a right to recover under FELA for negligently inflicted emotional distress, so the "merit" of a FELA claim of this type cannot be ascertained without reference to the common law. ${ }^{85}$

Instead, Justice Thomas adopted one of the common law limitations, the zone of danger test, because that test was the most liberal existing many years earlier when the statute was passed (thus fitting the statute's remedial purpose), is still in use today by a significant (if dwindling) number of states, and reasonably reconciled the competing interests at stake. ${ }^{86}$ Thus, an evolutionary interpretation of a common law statute requires attention not only to statutory purpose but also to common law decisions today and when the statute was passed.

If we assume that the Sherman Act was intended to evolve along with the common law of restraints on trade, what does that common law look like today? We can see the outlines of the answer in the Restatement (Second) of Property. ${ }^{87}$ Section 187 provides: "A promise to refrain from competition that imposes a restraint that is not ancillary to an otherwise valid transaction or relationship is unreasonably in restraint of trade." This is not a rule that would shock the modern antitrust lawyer. The antitrust lawyer might find section 188(1) a little more jarring:

A promise to refrain from competition that imposes a restraint that is ancillary to an otherwise valid transaction or relationship is unreasonably in restraint of trade if

(a) the restraint is greater than is needed to protect the promisee's legitimate interest, or

(b) the promisee's need is outweighed by the hardship to the promisor and the likely injury to the public.

These clauses do embody something like the antitrust rule of reason, but they are broader, in allowing broad consideration of the "public interest," not just economic welfare, and in making "hardship" a separate factor. ${ }^{88}$

85. Id. at 551 .

86. Id. at 554-55. For a critique of Gottshall, characterizing it as a "strikingly limited" exercise of common law decisionmaking, see Peter Strauss, Resegregating the Worlds of Statute and Common Law, 1994 SUP. CT. R. 429, 433.

87. Legal doctrine does not seem to have evolved much since the Second Restatement was issued, as shown by the similar statement of the rules in E. ALLAN FARNSWORTH, CONTRACTS 332-36 (3d ed. 1999).

88. Handler \& Lazaroff, supra note 64 , at 730-50, argue that the Restatement errs in giving independent weight to the hardship factor. They admit that numerous cases refer to this factor, but they contend that it is always either dictum or subsumed within the application of more focused tests of reasonableness. Id. at 740-50. For present purposes, it is unnecessary to determine whether the First Restatement or the Second 
Comment (c) explains:

Even if the restraint is no greater than is needed to protect the promisee's interest, the promisee's need may be outweighed by the harm to the promisor and the likely injury to the public. In the case of a sale of a business, the harm caused to the seller may be excessive if the restraint necessitates his complete withdrawal from business; the likely injury to the public may be too great if it has the effect of removing a former competitor from competition.... In the case of a postemployment restraint, the harm caused to the employee may be excessive if the restraint inhibits his personal freedom by preventing him from earning his livelihood if he quits; the likely injury to the public may be too great if it is seriously harmed by the impairment of his economic mobility or by the unavailability of the skills developed in his employment. ... Not every retraint causes injury to the public however, and even post- employment restraint may increase efficiency by encouraging the employer to entrust confidential information to the employee.

In considering the public interest, non-economic factors may also be relevant: for example, the Reporter's Comment (c) says "it would seem self-evident that the public interest is greater when access to serving professionals, especially physicians, is restricted, than it is when a purely business transaction is involved." In short, economic efficiency is not foreign to the Second Restatement analysis, but it is not the sine qua non. Note, for example, that market power does not figure anywhere in the analysis.

This is not to say that a textualist antitrust law would have to follow the Restatement slavishly, particularly where the Restatement differed from the law of 1890 or where a significant number of state courts apply different rules of contract law. But neither would the Court feel free to do in antitrust cases what the lower court did in Gottshall, which is to define a statutory purpose and pursue it without regard to the strictures of the common law. The freewheeling policy-making of modern antitrust law is quite foreign to the approach elaborated in Gottshall.

For present purposes, we need not choose between the cautiously dynamic and the static versions of textualist interpretation of common law terms. Neither interpretation would have allowed anything like the Supreme Court's modern approach to the Sherman Act as an exercise in applied economics. Nor is it necessary for us to defend either interpretation as correct in some ultimate sense, or as representing ideal social policy. For textualists, these are supposed to be at best secondary considerations.

Restatement is most accurate; neither one has much resemblance to modern antitrust doctrine. 
We are somewhat sensitive, however, to the possible accusation that we are setting up a strawman, in order to saddle textualists with an untenable interpretation. Admittedly, at least some textualists might be unfazed by such "policy" arguments or by the risk of an "absurd" interpretation anyway, but we do not wish to foist this position on them. But we do not believe that even the static interpretation of the Sherman Act, let alone the Gottshall-type interpretation, is absurd, however far it might be from current antitrust doctrine. Rather, we see several plausible arguments for the static interpretation.

First, the static interpretation would be far from rendering the Sherman Act a hollow exercise. ${ }^{89}$ Although the same acts would be unlawful under the common law and the statute, the statute creates far more stringent sanctions, including criminal penalties, government enforcement actions, and private causes of action. Also, enforcement would be moved to the federal courts, so that it would not be necessary to rely on state judges who might be corrupt or politically indebted to big business. Thus, the traditional restraints would be far more effective. As Judge Taft explained, in what is often considered to be the most important of the early decisions interpreting the statute:

[I]t is certain that, if the contract of association which bound the defendants was void and unenforceable at the common law because in restraint of trade, it is within the inhibition of the statute if the trade it restrained was interstate. Contracts that were unreasonable restraint of trade at common law were not unlawful in the sense of being criminal, or giving rise to a civil action for damages in favor of one prejudicially affected thereby, but were simply void, and were not enforced by the court. The effect of the act of 1890 is to render such contracts unlawful in an affirmative or positive sense, and punishable as a misdemeanor, and to create a right of civil action for damages in favor of those injured thereby, and a civil remedy by injunction in favor of both private persons and the public against the execution of such contracts and the maintenance of such trade restraints. ${ }^{90}$

Thus, viewing the Sherman Act as remedial-providing a new set of remedies for conduct that was already unlawful-is not at all farfetched.

89. It is, however, possible that the Sherman Act was not in intended to have very much impact. It is said that " $[\mathrm{m}]$ any contemporary lawyers believed that the approach Congress chose in the Sherman Act, based on the common law of restraints on trade, ... reflected a certain lack of enthusiasm for doing any more than convincing the public that they had done something." AREEDA, 1 ANTITRUST LAW, supra note 66, para. 102, at 17 (emphasis in original).

90. United States v. Addyston Pipe \& Steel Co., 85 F. 271, 278-79 (6th Cir. 1898), modified and aff'd, 175 U.S. 211 (1899). It should be noted that Taft did not exclude the possibility that the statute might reach some agreements that would have been lawful at common law. 
Second, although violation of the Sherman Act was originally only a misdemeanor, there can be no doubt that it was a penal statute. Indeed, section 6 allowed forfeiture of any property owned under any illegal contract, combination, or conspiracy, if that property was "in the course of transportation from one state to another." This was a serious penalty: railroads were among the potential targets of the statute, and all of their rolling stock was potentially subject to forfeiture. Application of the rule of lenity seems quite warranted here. ${ }^{91}$ These considerations argue strongly for taking seriously the statute's use of common law terms with well-established meanings, rather than adopting a more free-wheeling form of interpretation. ${ }^{92}$

Third, without delving into the confusing legislative history of the statute or its surrounding political context, it seems fair to say that the Sherman Act was as much designed to stop unfair business methods as to promote competitive markets. ${ }^{93}$ Whether or not the static common law interpretation is what members of Congress intended, it does not seem any more remote from their intentions than the Court's current interpretation. Of course, for the textualist, congressional intent is theoretically irrelevant, but even a staunch textualist might be reluctant to

91. The rule of lenity has been applied even when a civil remedy is sought when the statute also provides criminal penalties. See Crandon v. United States, 494 U.S. 152, 158,168 (1990). Having made the statute into an open-ended grant of judicial lawmaking, the modern Court has sought to confine the resulting vagueness through a mens rea requirement. See United States v. U.S. Gypsum Co., 438 U.S. 422 (1978). But this does not obviate the application of the rule of lenity-indeed, the prototypical application of the rule of lenity is to garden-variety criminal statutes which customarily include mens rea requirements.

92. One predictable objection is that the textualist interpretation of the Sherman Act would be unpredictable or indeterminate because applying the rule of reason involved multiple factors such as coercion, fairness, and public interest. The obvious response is that the task cannot be all that intractable, for common law courts have engaged in it for centuries in applying the common law doctrine of restraint of trade. An extensive body of case law would provide guidance on the statute's application.

93. The meaning of the legislative history is hotly contested. The most important literature on the subject is collected in E. Thomas Sullivan, The Political ECONOMY OF THE SHeRMAN ACT: THE FIRST ONE HUNDRED YEARS 20-160 (1991). For more recent discussion, see David McGowan, Innovation, Uncertainty, and Stability in Antitrust Law, 16 BERKELEY L.J. 729, 742-52 (2001). So far as we are aware, the legislative history has not yet been subjected to the kind of theoretically informed analysis found in Daniel Rodriguez \& Barry Weingast, The Positive Political Theory of Legislative History: New Perspectives on the 1964 Civil Rights Act and Its Interpretation, $151 \mathrm{U}$. PA. L. REV. 1417 (2003). 
construe what is supposed to be a major piece of legislation in way that made it nugatory. ${ }^{94}$ That is not true here.

Fourth, the current interpretation of the statute is actively at odds with the text. Interpreting both sections 1 and 2 to be about the same thingcompetitive markets - creates a textual anomaly. Section 1 prohibits all contracts or combinations in restraint of trade, while section 2 makes it unlawful for any person to "combine or conspire with any other person or person to monopolize." 95 This clearly implies that a conspiracy or combination to monopolize is not a form of a conspiracy or combination to restrain trade. Otherwise, it would have been unnecessary to refer to combinations and conspiracies in section 2 , because they would already have been covered by section 1. But if agreeing to form a monopoly is not a restraint of trade, why would acquiring some lesser market share be considered one? Thus, it is textually implausible - and violative of the "whole act" and "surplusage" canons-to interpret section 1 as relating to market power. ${ }^{96}$ Modern antitrust doctrine makes the conspiracy to monopolize portion of section 2 redundant, since such a conspiracy is necessarily a violation of section 1 . In contrast, reading section 1 to be concerned with unfair contract terms and coercion of third parties, while section 2 addresses market power, gives meaning to all of the words of the statute.

As a matter of historical reality, interpretation of the Sherman Act did not in the end follow the textualist lines advocated by Holmes. Instead, the statute was seen as a formless vessel to be filled with the Supreme Court's own theories of economic policy. In the next section, we consider whether any more specific content could have been extracted from later antitrust statutes, and whether those statutes could have usefully helped shape interpretation of the Sherman Act. For purposes of that analysis of later statutes, we take as given the Court's current view of the Sherman Act, notwithstanding the strong textualist arguments against that interpretation.

Of course, the fact that Congress found it necessary to pass these later

94. But see Justice Thomas's willingness to shrink into insignificance a major 1982 amendment to the Voting Rights Act, text accompanying infra notes 165-68.

95. The original terms of the Sherman Act are quoted by the Northern Securities majority, 193 U.S. at 318-19.

96. One might argue that Congress intended conspiracy charges under section 2 to be a lesser included offense of section 1 conspiracy. But since no different punishment is imposed, this seems unlikely. If Congress meant to allow cumulative punishment under the two sections, the odd result would be that a group of people who unsuccessfully conspired to monopolize trade would be subject to twice the punishment of a person who succeeded in doing so, and also twice the punishment of those who successfully gouged consumers through price fixing or group boycotts. Perhaps some argument might be concocted to support this difference in treatment, but it is a bit difficult to imagine. 
statutes proves that Congress has not been content with the "empty vessel" theory of antitrust. If Congress had only wanted to leave courts free to make economic policy, it would hardly have needed to pass further legislation after the Sherman Act. When the Supreme Court explicitly adopted the "rule of reason" standard, Democrats were horrified at this grant of "vast and undefined power" to the courts. ${ }^{97}$ In proposing the new legislation that became the Clayton Act, President Wilson called for a statute describing anticompetitive practices "explicitly and item by item . . . in such terms as will practically eliminate uncertainty." "98 When it passed the FTC Act, Congress believed that the "most certain way to stop monopoly at the threshold is to prevent unfair competition," and that "[i]t is impossible to frame definitions which embrace all unfair practices"; the solution was a broad mandate to the FTC to interpret its meaning. Both statutes can be seen as responses to concerns about judicial policymaking: the Clayton Act by trying to provide more explicit guidelines for courts, and the FTC Act by shifting the policymaking task away from the courts to an administrative agency. As we will see, however, courts stubbornly maintained their policymaking discretion notwithstanding these efforts by Congress.

\section{B. The Clayton Act and other Statutes}

The Sherman Act obviously was not Congress's final word on antitrust. Congress subsequently enacted several major antitrust statutes: the Clayton Act (1914), the Federal Trade Commission Act (1914), and the Robinson-Patman Price Discrimination Act (1936). The Clayton Act and the Robinson-Patman Act both dealt with more limited, specificallydefined phenomena than the Sherman Act, with somewhat more focused and specific statutory language. Under standard textualist analysis, courts should focus mainly on the language of the more recent and more specific statutes in the areas in which they apply. Yet, as we shall see, the Supreme Court has instead tried to assimilate these two statutes into the general economic policy-driven analysis it has derived from the Sherman Act. The Federal Trade Commission Act, in contrast, does indeed amount to a broad Congressional delegation of power to create

97. William Letwin, Law and Economic Policy in America: The Evolution OF THE SHERMAN ANTITRUST ACT 269 (1965) (quoting Senator Cummins).

98. Id. at 273. A detailed legislative history of these statutes can be found in Marc Winerman, The Origins of the FTC: Concentration: Cooperation, Control, and Competition, 71 ANTITRUST L.J. 1 (2003-2004). 
antitrust rules. The delegation, however, is to the Federal Trade Commission, not the courts, creating another set of concerns for a textualist confronted with existing Supreme Court antitrust doctrine. In this section we discuss several specific topics where the text of the later antitrust acts provides a significant amount of guidance on disputed matters. This is not, of course, anything like a comprehensive survey of antitrust law, nor do we claim that textualist readings could provide solutions to all of the many disputed matters in antitrust. Our claim is more limited: reading the statutory text gives us guidance on some significant set of antitrust questions. We will consider briefly the question of what to do where the text provides little guidance in Part IV.

\section{The Clayton Act, Mergers, and the Efficiency Defense}

Section 7 of the Clayton Act, as amended by the Celler-Kefauver Act of 1950, prohibits acquisitions of the assets or stocks of another person "where in any line of commerce or in any activity affecting commerce in any section of the country, the effect of such acquisition, of such stocks or assets, or of the use of such stock by the voting or granting of proxies or otherwise, may be substantially to lessen competition, or to tend to create a monopoly." 99 As Courts have correctly held, the "substantially to lessen competition" language goes beyond the "monopolize" language of section 2 of the Sherman Act. Section 7 thus has become the main statutory language to analyze when considering the legality of a merger between companies.

One issue that periodically arises in analyzing mergers is whether increased efficiencies that a merger may create can ever justify a merger that would otherwise be illegally anti-competitive. Imagine a merger of two businesses which significantly increases their market share and their ability to set prices above marginal cost, but which also greatly increases the operating efficiency of the businesses, say by enabling the realization of economies of scale. Suppose the efficiency gains are enough to clearly outweigh the efficiency losses due to increased monopolization of the market. Should such a merger be allowed? That is, should the companies, if accused of violating section 7 of the Clayton Act, be able to plead increased efficiency as a defense which justifies the merger?

Several Warren-era Supreme Court cases suggest the answer is no. ${ }^{100}$ More recent lower court cases, though, have been willing to consider an efficiency defense, although they have been reluctant to find that the

99. 15 U.S.C. $\$ 18$.

100. See Brown Shoe v. U.S., 370 U.S. 294; FTC v. Procter \& Gamble, 386 U.S. 568 (1967). 
defense is satisfied on the facts in the cases before them. ${ }^{101}$ The Department of Justice and FTC Horizontal Merger Guidelines provide for a limited efficiencies defense. ${ }^{102}$ The leading antitrust treatise advocates a limited efficiency defense, ${ }^{103}$ although Judge Posner, one of the main innovators in economics policy-based antitrust law, has been skeptical about the efficiency defense. ${ }^{104}$

Is a merger efficiency defense consistent with the language of the Clayton Act? Let us distinguish two cases. In case 1, two smaller firms within an oligopolistic industry merge, and their enhanced efficiency makes the new firm a better competitor with the larger firms in the industry. As a result, collusion becomes harder to maintain. In case 2, two firms within an oligopolistic industry merge, and their enhanced efficiency, with resulting lower costs, makes the new firm better able either to monopolize the industry (by having lower costs than its competitors) or else to act as a leader in coordinating collusive behavior. Either monopoly or more disciplined oligopoly results, but production is significantly more efficient than before the merger. That is, total surplus increases as a result of the merger, although consumers surplus may increase or decrease.

In this situation, an efficiency defense makes sense within the statutory language in case 1 . Indeed, the word "defense" is misleading. In that case competition has been increased, not decreased, on most sensible understandings of the word "competition." The industry may be more concentrated according to a simple measure like the HHI, but individual firms are less able to set prices, quantities, and quality without worry

101. See United States v. Rockford Memorial Corp., 717 F. Supp. 1251, 1291 (N.D. I11. 1989), aff'd, 899 F.2d 1278 (7th Cir.), cert. denied, 498 U.S. 920 (1990) (rejecting efficiency defense because efficiencies not great enough); FTC v. University Health, 938 F.2d 1206, 1222 (11th Cir. 1991) (same); FTC v. Staples, 870 F. Supp. 1066 (D.D.C. 1997) (same); United States v. United Tote, 768 F. Supp. 1064, 1084-85 (D.Del. 1991) (same); United States v. Carillon Health Sys., 707 F. Supp. 840, 849 (D. W. Va.), aff'd, 892 F.2d 1042, 1084-85 (4th Cir. 1989) (approving merger because anticompetitive effects not proven and noting evidence of efficiencies); United States v. Country Lake Foods, 754 F. Supp. 669, 680 (D. Minn. 1990) (approving merger in market definition analysis and noting efficiencies); see also AREEDA, IVA ANTITRUST LAW, infra note 103, para. 970c.

102. 1992 Merger Guidelines $\S 4$.

103. See Phillip E. Areeda, Herbert Hovenkamp, \& John L. Solow, IVA ANTITRUST LAW ch. 9E (1998) [hereinafter IVA ANTITRUST LAW].

104. See Richard A. POSNER, ANTTTRUST LAw 133-36 (2nd ed. 2001). His skepticism is based on efficiency and administrability grounds, not textualist grounds. 
about the reaction of their competitors. That sounds like increased competition as understood by the man on the street, businessmen, members of Congress, or an economist. Thus, on any plausible account of the term "competition," the effect of a case 1 merger is not "substantially to lessen competition."

A merger defense is much harder to justify textually in case 2 , however. In case 2 , the post-merger firm is by hypothesis more able to set prices and quantities at a level it prefers without fearing a reaction from other firms than was the case pre-merger. Although the man in the street, businesspeople, members of Congress, and economists, may all understand the term "competition" in a variety of ways, we find it hard to believe that anyone would understand case 2 as not involving a lessening of competition. If we look to the ordinary meaning of "compete" using that most textualist of devices, a dictionary, Merriam-Webster defines competing as contending, ${ }^{105}$ while the American-Heritage Dictionary defines it as striving with others. ${ }^{106}$ If we instead consider how economists define the term, we see that they have created a notion of perfect competition whereby a firm in a perfectly competitive market must take prices as given-if it tries to set prices higher than the market level, it will have no sales, and the firm is small enough that other firms will not react to changes in price or output by the individual firm. ${ }^{107}$ These two notions of competition diverge in important ways, which in some circumstances may have differing implications for antitrust law. ${ }^{108}$ However, on both understandings of the word, competition has decreased in case 2 .

Is there any way to make an efficiency defense in case 2 consistent with the statutory language? One way would be to argue that where significant efficiencies are available, then if the government blocks a merger someone will achieve those efficiencies anyway through internal expansion, and in the end competition will lessen the same amount either way. Thus, some argue, we should see the available efficiencies, and not the merger, as the true cause of the ultimate lessening in competition. ${ }^{109}$ However, this argument is somewhat speculative, and therein lies its downfall. Maybe internal expansion will occur rapidly if no merger occurs, but maybe not. If the argument is right and internal expansion would occur rapidly, then there is little need for an efficiency defense in

105. See The Merriam-Webster Dictionary 164 (5th ed. 1997).

106. See THE AMERICAN HERITAGE DictionARY 178 (3rd ed. 1994).

107. See Hal R. VARIAN, Microeconomic ANAlysis 82 (2nd ed. 1984).

108. See Harry S. Gerla, Restoring Rivalry as a Central Concept in Antitrust Law, 75 NEB. L. REV. 209 (1996).

109. See AreEda, HovenKamP, \& Solow, IVA ANTITRUST Law, supra note 103, at $970 \mathrm{c} 1$. 
the first place if one's aim is maximizing efficiency. The market will reach the efficient outcome either way, whether or not the government allows a merger to proceed. In this case, blocking the merger may be ineffectual, but it is not inefficient.

Alternatively, internal expansion might not occur, or it might occur only slowly. ${ }^{110}$ In this case failing to allow for an efficiency defense may indeed lead to inefficiency. However, in this case it is also clear that the merger itself is reducing competition, at least for the period of time before internal expansion would occur in the absence of a merger. Thus, in this case the efficiency defense does not fit within the statutory language.

We conclude that a textualist reading of the Clayton Act does not permit an efficiency defense to a case 2-type merger, although increased efficiency may be relevant to determining the likely effects on competition in a case 1-type situation.

\section{The Robinson-Patman Act, Price Discrimination, and Predatory Pricing}

Section 2 of the Clayton Act prohibited price discrimination that has the effect of substantially lessening competition. It provided:

It shall be unlawful for any person engaged in commerce, in the course of such commerce, either directly or indirectly to discriminate in price between different purchasers of commodities, which commodities are sold for use, consumption, or resale within the United States or any Territory thereof or the District of Columbia or any insular possession or other place under the jurisdiction of the United States, where the effect of such discrimination may be to substantially lessen competition or tend to create a monopoly in any line of commerce...

By the 1930s many believed that this did not provide adequate protection against price discrimination. In particular, there was concern about the spread of national chain stores which were able to obtain goods at discounts, giving them a major cost advantage against smaller, local competitors. In response, Congress passed the Robinson-Patman Act in 1936. The Act amended section 2 of the Clayton Act to read, in part:

110. Recognizing the weight of the proceeding argument against the merger defense, the treatise authors defending the defense argue that in a variety of circumstances internal expansion may not occur, or may occur slowly. See id. at $973 \mathrm{~b}$. 
It shall be unlawful for any person engaged in commerce, in the course of such commerce, either directly or indirectly, to discriminate in price between different purchasers of commodities of like grade and quality, where either or any of the purchases involved in such discrimination are in commerce, where such commodities are sold for use, consumption, or resale within the United States or any Territory thereof or the District of Columbia or any insular possession or other place under the jurisdiction of the United States, and where the effect of such discrimination may be substantially to lessen competition or tend to create a monopoly in any line of commerce, or to injure, destroy or prevent competition with any person who either grants or knowingly receives the benefit of such discrimination, or with customers of either of them....

This provision aims at two different kinds of harm to two different kinds of persons. The first is harm to businesses competing with the firm which price discriminates; this is "primary-line injury." 111 The second is harm to businesses competing with the firm which receives the benefit of the price discrimination; this is "secondary-line injury." $112 \mathrm{We}$ shall concentrate on primary-line injury, that is, injury to the supplier's competitors rather than the buyers'.

Law and economics scholars tend to be quite contemptuous of the Robinson-Patman Act. This contempt has made its way into Supreme Court decisions. Economists tend to see price discrimination as frequently efficiency-enhancing. Price discrimination involves charging a different price to different persons for the same good with the same costs. ${ }^{113}$ Economists view price discrimination as potentially beneficial. They point out that price discrimination frequently allows monopolists to raise output above the one-price monopoly level, removing some of the inefficiency which monopoly creates, although also transforming consumer surplus into producer surplus. ${ }^{114}$ Critics of Robinson-Patman note that it emerged from a populist fear of big chain stores or to put it another way, from a desire to protect inefficient small stores from their larger, more efficient competitors.

Analysis of primary-line injury heavily overlaps with analysis of predatory pricing. Predatory pricing generally occurs where a business engages in below-cost pricing in order to drive competitors away, so that it can subsequently charge monopoly prices. The Supreme Court analyzes

111. See Herbert Hovenkamp, 14 Antitrust Law para. 2301 (1999).

112. See id.

113. That is the legal definition. The economic definition is receiving different returns from different customers. The two may vary if costs differ for different customers. In that case, returns may be the same even if prices differ, or prices may be the same even if returns differ.

114. See Phillip E. Areeda \& Herbert HovenKamp, 3 Antitrust law para. $721 \mathrm{~d}$ (1996). 
predatory pricing under section 2 of the Sherman Act. Where the predatory pricer is charging different prices to different customers, then the Robinson-Patman Act also potentially applies, and the question arises as to how to treat the two statutes in tandem. Price discrimination may make it easier to engage in predatory pricing by allowing the predation to occur only with some customers, so that the predator continues to earn normal or monopoly returns from its other customers.

In predatory pricing cases not involving price discrimination, the Court in recent decades has been reluctant to find antitrust liability. It has required plaintiffs to show both that the defendant set prices below cost and that there was a good chance that the defendant was able to recoup losses from the period of predatory pricing through later monopoly pricing. ${ }^{115}$ The Court has said that these requirements will be met only infrequently. Chicago-school economic analysis has strongly influenced the Court's analysis. This economics-based analysis, however, is in serious tension with Robinson-Patman, which views price discrimination with far greater skepticism.

We get a revealing look at how the Court currently analyzes these issues in Brooke Group Ltd. v. Brown \& Williamson Tobacco Corp. ${ }^{116}$ The case involved the generic cigarette industry. Liggett pioneered this branch of the cigarette industry, in which prices are much lower than the prices for most branded cigarettes. Liggett alleged that Brown \& Williamson entered the generic market and engaged in aggressive pricing, including volume discounts and different prices for different wholesalers. Liggett's theory was that Brown \& Williamson was trying to pressure Liggett to engage in oligopolistic pricing in the generic market. Both companies were among the smaller of the six major companies in the highly concentrated cigarette market, in which oligopolistic pricing had occurred for many years. Liggett charged that Brown \& Williamson's generic market tactics succeeded, and that eventually every company in the market got in line and raised prices in lockstep twice every year, at the same time that they similarly raised prices of branded cigarettes.

Brown \& Williamson unquestionably engaged in price discrimination and offered no affirmative defense. The case thus hinged upon whether Liggett had succeeded in presenting enough evidence to sustain a jury finding of the requisite competitive injury. Writing for the majority,

115. See Matsushita Elec. Industrial Co. v. Zenith Radio Corp., 475 U.S. 574, 585 n.8, 589 (1986).

116. 509 U.S. 209 (1993). 
Justice Kennedy (a textualist in some opinions but not here) assimilates the later, more specific Clayton and Robinson-Patman Acts to the Court's understanding of policy derived from the Sherman Act: "primary-line competitive injury under the Robinson-Patman Act is of the same general character as the injury inflicted by predatory pricing schemes actionable under $\S 2$ of the Sherman Act." 117 The only difference is that Robinson-Patman requires that there be a "reasonable possibility of substantial injury to competition," whereas the Sherman Act requires "a dangerous probability of actual monopolization." 118 But this seems to be a distinction without a difference, given the Court's skepticism that either standard can ever be met.

The Court thus invokes its predatory pricing doctrine under the Sherman Act, mentioned above, requiring the plaintiff to show below cost pricing and a reasonable prospect of recouping its investment in below-cost prices. ${ }^{119}$ The Court expects plaintiffs will generally fail to show these prerequisites to recovery are met: "As we have said in the Sherman Act context, "predatory pricing schemes are rarely tried, and even more rarely successful.""120 The Court thus states that it is unwilling to apply section 2 of the Clayton Act or the Robinson-Patman Act except in highly limited circumstances, because under its preferred economic theories those statutes usually make little sense. The result may (or may not) be good economic theory, but it surely is not what the words of the statutes seem to direct. On its face this should make any good textualist deeply unhappy.

On the Court's theory, if garden-variety predatory pricing usually fails, predatory pricing by multiple firms to enforce an oligopolistic pricing scheme is even more likely to fail because of the difficulties of collective action among firms trying to collude. ${ }^{121}$ The Court thus sets the evidentiary bar extremely high. An earlier case much maligned by law and economics types, Utah Pie v. Continental Baking Co., ${ }^{122}$ suggested that proof of defendant intent to harm competition through below-cost pricing was enough to establish the required injury. The Supreme Court rejects that notion. It admits that there was adequate evidence suggesting that Brown \& Williamson did indeed intend to price below cost in order

117. Id. at 221 .

118. Id. at 222 .

119. See id. at 222-24.

120. Id. at 226. Many but far from all economists share this skepticism about the dangers of predatory pricing. Such skepticism is characteristic of a Chicago School, laissez-faire approach, but other economists question it. See Patrick Bolton et. al., Predatory Pricing: Strategic Theory and Legal Policy, 88 GEO. L.J. 2239 (2000).

121. See id at 227-28.

122. 386 U.S. 685 (1967). 
to induce Liggett to get in line with the oligopoly, and that it did indeed price below cost for about 18 months. ${ }^{123}$ But, says the Court, that is not enough for a jury to infer that Brown \& Williamson had a reasonable prospect of profiting from this scheme. ${ }^{124}$

So, Brown \& Williamson, an experienced and successful company with many decades of intimate knowledge of this industry, apparently believed that it could better its profits by forcing Liggett back into line through a price war, but Justice Kennedy and his colleagues, armed with the best economic theory Chicago has to offer, know better-Brown \& Williamson was just wasting its shareholders' money. How arrogant. How implausible. ${ }^{125}$ Note that in accepting a highly contestable and specific economic theory, the Court ignores a much more general and basic piece of wisdom from economics: we should generally presume that experienced actors within an industry are rationally pursuing their goals.

Of even more concern to us here, see what the Court's reasoning has done to primary-line injury under the Robinson-Patman Act. We are dealing here, after all, with important language from two different acts, Robinson-Patman and Clayton, which attempted to extend the reach of antitrust law beyond judicial interpretations. Yet, the Court by its own reckoning has made the requisite evidence in primary-line cases so difficult to establish that defendants will rarely be liable. In Brooke Group, the Court successfully waged war, in the name of economics, on the statutory language Congress gave us, and gave that language nearly no effect. Although many have derided it, the Utah Pie decision to allow evidence of intent to establish the required injury fits the statutory language much better than the reasoning in Brooke Group. Although the statute does not refer to intent, Utah Pie does give significant scope for application of the Robins-Patman Act language, which Brooke Group does not do. Moreover, the statute does speak of whether the "effect of such discrimination may be to substantially lessen competition," "126 and

\section{See id. at 231.}

124. See id.

125. In his dissent Justice Stevens-notably, the only antitrust litigator on the Court-points out the Court's naive self-satisfaction. In response to the majority's statement that an "anticompetitive minuet is most difficult to compose and to perform", Stevens noted that "the professional performers who had danced the minuet for 40 to 50 year would be better able to predict whether their favorite partners would follow them in the future than would an outsider, who might not know the difference between Haydn and Mozart." Id. at 257-58 (Stevens, J. dissenting).

126. 15 U.S.C. $\$ 2$ (emphasis added). 
given only very weak rationality assumptions about economic actors, where there is intent to substantially limit competition, it is highly plausible to infer that such action may have its intended effect.

Given the Court's extreme skepticism about the ability to use predatory pricing to enforce collusion between oligopolists, should the Court have simply created a per se rule that such a theory can never give rise to liability? One can read the Court of Appeals opinion as creating such a rule. The Court, however, refuses to go that far. Its justification is an island of textualism within a sea of dynamic statutory interpretation. The Court notes that while the Sherman Act refers only to express agreement and monopoly, "the Robinson-Patman Act is phrased in broader, disjunctive terms, prohibiting price discrimination 'where the effect of such discrimination may be substantially to lessen competition or tend to create a monopoly." 127 It then cites the textualist canon that all of the words of the Act must carry adequate meaning, inferring that this language must go beyond the Sherman Act. ${ }^{128}$ Moreover, the Court notes that the language was part of the original Clayton Act, and that the same phrasing occurs in section 7. In that context the Court has held that oligopolistic price coordination can be the required injury to competition, and identical words in different parts of the same act should be given the same meaning, another classic textualist canon. ${ }^{129}$ The Court thus refuses to declare the conduct in this case per se legal. However, we have already seen that it goes so far that it might as well have done so. As construed here, the Clayton and Robinson-Patman Act go just a smidgen beyond the Court's policy-driven interpretation of the Sherman Act.

It gets worse. What we have suggested so far is that, in the context of primary-line price discrimination, the Court gives extremely little effect to the Clayton Act language concerning "where the effect of such discrimination may be substantially to lessen competition or tend to create a monopoly." We have not yet considered the injury language which Robinson-Patman added: "or to injure, destroy, or prevent competition with any person who either grants or knowingly receives the benefit of such discrimination, or with customers of either of them."130 By the same canon we just considered, a good textualist must interpret this language as adding in new circumstances of possible liability due to a new type of competitive injury beyond the Sherman or Clayton Acts. In short, this language must forbid price discrimination in some circumstances where

127. Id at 229. The quoted statutory language is actually from the Clayton Act. We shall consider the implications of that mistake below.

128. See id.

129. Id.

130. 15 U.S.C. $\S 13(\mathrm{a})$. 
there is no immediate prospect of monopolization or market power. What does the Court do with this language?

Nothing at all. It ignores the language.

What might a Court that consistently cared about the text do with this language? In secondary-line cases, courts have interpreted the language as creating liability for simple injury-in-fact to individual competitors of the companies that receive the lower prices. ${ }^{131}$ The obvious suggestion would thus be that in primary-line cases courts should interpret the language as creating liability for injury-in-fact to individual competitors of the company engaged in price discrimination. However, that would go against the old saw that the Court repeats here: "It is axiomatic that the antitrust laws were passed for 'the protection of competition, not competitors."' 132 Indeed, the statute speaks of injury to competition with persons, not of injury to competitors, providing some textual support for this engrained position ${ }^{133}$ But note that Robinson-Patman does distinguish between injury to competition in a line of commerce and injury to competition with a single firm. Thus, a textualist interpretation of the statute should respect both (a) the distinction between marketwide and competitor-specific injury, and (b) the distinction between injury to competitors and injury to competition.

However this language is interpreted, the current difference in treatment of primary- and secondary-line injuries on this point is textually hard to defend. The statute speaks of injury to competition with two types of persons: those who grant price discrimination, and those who knowingly benefit from it. The first is primary-line injury, while the second is secondary-line injury. The injury to competition for each should be similarly defined. ${ }^{134}$ Moreover, as we have already seen, the injury should go beyond simply a reasonable prospect of harm to competition in the market as a whole, as the old Clayton Act language covers that.

A possible textualist resolution is as follows. For the Clayton Act language, plaintiffs must show a reasonable possibility that the price discrimination will cause enough injury to competition to qualify as

131. See, e.g., Chroma Lighting v. Gte Products Corp., 111 F.3d 653 (9th Cir. 1997); Rebel Oil Co. v. Atlantic Richfield Co., 51 F.3.d 1421 (9th Cir. 1995); George Haug Co. v. Rolls Royce Motor Cars, 148 F.3d 136 (2nd Cir. 1998); see also HOVENKAMP, supra note 111, para. 2342d.

132. Brooke Group, 509 U.S. at 224 (citation omitted).

133. See HovenKamP, supra note 111, para. 2342d; Hovenkamp, The RobinsonPatman Act and Competition: Unfinished Business, 68 ANTITRUST L.J. 125, 133-35 (2000).

134. Hovenkamp makes the same point. See id. 
"substantially lessening" competition. If, however, plaintiffs show injury to a particular person, then they only need show a reasonable possibility ${ }^{135}$ that such injury will harm competition in the relevant market-but that harm need not be substantial. For example, any tendency to reinforce oligopolistic pricing or to further a trend toward market concentration would be sufficient. However, practices which harmed individual competitors but very likely helped competition overall would not be prohibited.

This resolution would make it easier to prove primary-line injury than is currently the case under Brooke Group. However, it would make it a little harder to prove secondary-line injury than is currently the case in many circuits, which require only evidence of injury to competitors without reason to believe that such injury will harm competition generally at all. As this example illustrates, we need not continue the current practice of relegating the statutory text to an afterthought when applying the Robinson-Patman Act.

\section{The Federal Trade Commission Act and Congressional Delegation}

The Federal Trade Commission Act presents a quite different kind of textualist challenge to the reigning approach to antitrust interpretation. We briefly consider that challenge here.

Congress initially passed the Federal Trade Commission Act in 1914, at about the same time as the Clayton Act. ${ }^{136}$ The core substantive prohibition of the Act simply declares that "Unfair methods of competition in or affecting commerce, and unfair or deceptive acts or practices in or affecting commerce, are hereby declared unlawful."137 The FTC was to enforce this provision, mainly through case-by-case adjudication. ${ }^{138}$ The FTC was given some rulemaking power, which was long understood as limited to procedural and interpretative rules ${ }^{139}$ although the D.C. Circuit eventually decided that the FTC had authority to promulgate legislative rules, ${ }^{140}$ and Congress later explicitly gave the commission authority to

135. The reasonable possibility language is textually supported by the phrase "where the effect of such competition may be..." which applies to the RobinsonPatman Act language as well as the older Clayton Act language.

136. 38 Stat. 717-721 (1914).

137. 15 U.S.C. $\$ 45(a)(1)$.

138. See 15 U.S.C. $\$ 45(\mathrm{a})(2)$ ("The Commission is hereby empowered and directed to prevent persons, partnerships, or corporations . . . from using unfair methods of competition in or affecting commerce and unfair or deceptive acts or practices in or affecting commerce.").

139. See Thomas W. Merrill \& Kristin E. Hickman, Chevron's Domain, 89 Geo. L. J. 833, 874 n.222 (2001).

140. See Nat'l Petroleum Refiners Ass'n v. FTC, 482 F.2d 672, 678 (1973). 
promulgate interpretive rules and general statements of policy with respect to unfair or deceptive acts or practices. ${ }^{141}$ Under section 11 of the Clayton Act, the FTC has authority to enforce compliance with sections 2,3,7, and 8 of the Clayton Act in most industries. ${ }^{142}$

The FTC poses several challenges to existing interpretive understandings. First, consider the standard argument that the Sherman Act is written in such general terms that we must understand it as simply delegating discretionary power to the courts to develop a common law of antitrust. ${ }^{143}$ We have already suggested that the Sherman Act actually had much more shape than that through the use of pre-existing common law terms. The Federal Trade Commission Act shows that Congress does know how to delegate authority broadly in the antitrust area when it wants to. "Unfair methods of competition" is a new phrase without common law mooring, and the statute does nothing to define this broad phrase any further. Here is a truly broad delegation of authority. The second challenge arises from noticing the following: in the FTC Act Congress has indeed made a broad delegation of antitrust authority, but it is to the FTC, not the courts. This should come as no surprise. Antitrust raises tough, technical problems which require a sophisticated understanding of economics and business practices in order to be able to make sound policy. Detailed knowledge of the specific industry at issue is required. Agencies are much more likely to possess the required expertise than courts. ${ }^{144}$ Congress typically invests agencies, not courts, with wide discretion in such areas, and the FTC is an early example. We should be skeptical of judges trying to assert great discretionary authority in an area where Congress has given such authority to a specialized agency. ${ }^{145}$ And indeed, as we have already discussed, the FTC Act was not exactly

141. See 15 U.S.C. $\$ 57$ a. Note that this grant of authority applies only to unfair or deceptive acts or practices, not to unfair methods of competition.

142. See 15 U.S.C. $\S 21$.

143. See supra notes $161-63$ and accompanying text.

144. For similar reasons, a recent article argues that primary responsibility for competition policy should be moved to a new administrative agency. See Reza Dibadj, Saving Antitrust, 75 U. COLO. L. REV. 745 (2004).

145. See City of Milwaukee v. Illinois, 451 U.S. 304 (1981) (federal common law of interstate nuisance preempted by grant of regulatory authority to EPA). The Milwaukee Court relied on the comprehensive regulatory scheme. The FTC Act is clearly much less detailed and leaves much more discretion to the FTC. One could argue that Congress thereby vested less exclusive authority in the FTC than in the EPA. One could instead argue, though, that the greater discretion that Congress gave to the FTC signals an even stronger desire to leave major policy issues to the agency, not the courts. 
a sign that Congress was thrilled with the way the courts were handling antrust law.

This leads to the third, more doctrinal challenge. Given the grant of authority to the FTC, established canons strongly suggest that courts should give FTC interpretations of the Federal Trade Commission Act and the Clayton Act much deference. Whether the deference due should be Chevron ${ }^{146}$ deference or weaker Skidmore ${ }^{147}$ deference is not necessarily an easy question, and perhaps the answer differs for the two acts. ${ }^{148}$ At any rate, where the FTC has interpreted these acts, either in formal adjudication or in rulemaking, courts should generally follow the agency interpretation absent strong reason to believe that the agency has misunderstood the statute-a proviso likely to apply quite rarely in the case of the broad and vague mandate of the Federal Trade Commission Act, though one that may occur more frequently for the Clayton Act. Courts have only occasionally engaged in Chevron deference in the antitrust context, ${ }_{149}^{149}$ and the rare instances of Chevron deference have been at least as likely to defer to Justice Department interpretations as to the FTC. ${ }^{150}$ The failure to show greater deference to FTC interpretations of the antitrust statutes is just another example of how courts have diverged from traditional statutory interpretation principles in this area.

Such deference to agencies is a part of the contemporary textualist's toolkit. Textualists accept Chevron. ${ }^{151}$ In the antitrust context, deference to agency interpretations provides a major part of the answer to a leading criticism of textualism: in too many situations, the statutory text just

146. See Chevron U.S.A. Inc. v. Natural Res. Def. Council, Inc., 467 U.S. 837 (1984).

147. See Skidmore v. Swift \& Co., 323 U.S. 134 (1944).

148. For discussion of the two types of deference, see Merrill \& Hickman, supra note 139, at 853-63. For discussion of the application to FTC interpretation, see id. at 875 n.222.

149. See E. Thomas Sullivan \& Robert B. Thompson, The Supreme Court and Private Law: A Thirty-Year Retrospective of Economic Regulation in Securities and Antitrust 51 n.182 (working paper).

150. See Michigan Citizens for and Independent Press v. Thronburgh, 868 F.2d 1285,1291 (D.C. Cir. 1989) (deferring to Attorney General's interpretation of the Newspaper Preservation Act); Mattox v. FTC, 752 F.2d 116, 123 (5th Cir. 1985) (deferring to Justice Department and FTC interpretation of the Hart-Scott-Rodino Act).

151. See Atonin Scalia, Judicial Deference to Administrative Interpretations of Law, 1989 DUKE L.J. 511. Indeed, Justice Scalia is a leading backer of Chevron, see Merrill \& Hickman, supra note 139, at 859-60. However, in applying the first step of Chevron, confident textualists such as Justice Scalia will sometimes be more inclined than others to believe that the statutory text clearly provides an answer, and hence that the Court should not follow the agency's interpretation. See, e.g., MCI Telecommunications Corp. v. AT\&T, 512 U.S. 218 (1994); see Merrill \& Hickman, supra note 139, at 860. 
does not provide enough guidance. Even if this is often true, agency interpretations may provide the needed help. For example, in interpreting section 7 of the Clayton Act, it is not obvious how great an increase in market concentration counts as substantially lessening competition. The FTC and Department of Justice merger guidelines can fill this gap. Thus, textualism is less indeterminate in antitrust law than is often argued. It is thus another sign of Judge Easterbrook's divergence from his usual textualism when he notes approvingly courts' failure to follow Chevron in antitrust cases. ${ }^{152}$

\section{ENDING ANTITRUST EXCEPTIONALISM}

\section{A. Beyond the Delegation Theory}

In the previous section of this paper, we examined the antitrust statutes using the normal tools of textualism. While those tools do not suffice to eliminate all ambiguity from the statute, they would allow a textualist to attack a number of antitrust problems. The normal textualist reading would diverge in many ways from current doctrine. But a number of writers, including leading textualists, have argued that the normal tools of statutory interpretation do not apply to the antitrust laws. Instead, they view the antitrust laws, not as statutory mandates, but as delegations of lawmaking power to the courts.

Some examples will show how widespread this view is, both among textualists and others:

- William Baxter: "By adopting a common-law approach, Congress in effect delegated most of its lawmaking power to the judicial branch." 153

- Frank Easterbrook: "The statute books are full of laws, of which the Sherman Act is a good example, that effectively authorize courts to create new lines of law."154

152. See Krzalic v. Republic Title Co., 314 F.3d 875, 883 (Easterbrook, J. concurring) ("Interpretation differs fundamentally from regulation. Judges do not apply Chevron to the Attorney General's interpretation of the Sherman Antitrust Act, whether in public or in private litigation, although the antitrust statutes are notoriously open-ended.") Note, though, that this quote refers to Attorney General interpretation of the Sherman Act; the Federal Trade Commission and the Federal Trade Commission Act present a different question.

153. William Baxter, Separation of Powers, Prosecutorial Discretion, and the "Common Law" Nature of Antitrust Law, 60 TEX. L. REV. 661, 663 (1982).

154. Frank Easterbrook, Statutes' Domains, 50 U. CHI. L. REV. 533, 544 (1983). 
- John Manning: "Conventional delegations presuppose that agencies and courts will exercise their independent policymaking discretion within the boundaries set by the delegation." (citing the Sherman Act as an example). ${ }^{155}$

- Einer Elhauge: "To be sure, sometimes it will be clear that what the legislature means or preferred was to delegate the matter for ongoing judicial resolution. The antitrust statutes, for example, are commonly understood to involve such a delegation to the courts." 156

- Areeda and Hovenkamp: "[T]he Sherman Act effectively vested the federal courts with a power to make competition policy analogous to that of common law courts. . . "157

On reflection, however, we believe that this view is untenable. There is simply no reason to view the antitrust laws as a grant of legislative power to the courts.

One of the main arguments for the delegation theory is that the Sherman Act uses common law terms, and must therefore contemplate a common-law process of law development. We saw in Part III that this is an overstatement: there is a tenable argument that the statute incorporated the common law doctrine of 1890 and nothing more. But even assuming a more dynamic approach is taken, it is a caricature of the common law to equate it with judicial legislation. Indeed, if there is any genuine linkage between textualism and modern antitrust doctrine, it is the simplistic view of the common law that seems endemic among textualists. No one doubts that policy is an important factor in common-law decisions. But it is quite another thing to say, as Justice Scalia has said, that the "attitude of the common-law judge" is one that "asks, "What is the most desirable resolution of this case, and how can any impediments to the achievement of that result be evaded?"'158

It is this view of the common law that allows Scalia to summarize the reasoning of one of his own antitrust opinions as follows: "In sum, economic analysis supports the view, and no precedent opposes it, that a

155. John Manning, The Absurdity Doctrine; 116 HARV. L. REV. 2388, 2444-45 n.212(2003).

156. Einer Elhauge, Preference-Estimating Statutory Default Rules, 102 COLUM. L. REV. 2027, 2044 (2002).

157. AREEDA, 1 ANTITRUST LAW, supra note 66, at 63, para. 103. The treatise authors do admit that "[s]tatutory language sets some bounds", and that some of the words of the statute "may be somewhat elastic in meaning" but are not "entirely protean." Id. However, they seem to regard constraint by the statutory language as somewhat exceptional, not to mention regrettable.

158. Scalia, supra note 1 , at 13. 
vertical restraint is not illegal per se unless it includes some agreement on price or price levels. Accordingly, the judgment of the Fifth Circuit is Affirmed." 159 Unless perhaps the author was Judge Posner, it is hard to imagine a decision in a common law case basing its conclusion on the stark argument that economic analysis supported the result and no precedent opposed it. For instance, most common law judges would also wonder whether any precedent supported the result. When Congress contemplates common-law decisions by the courts, there is no reason to suppose that it had this kind of blatantly result-oriented decisionmaking in mind. There is particularly little reason to ascribe this view to Congresses that acted in the era of Swift $v$. Tyson, when it was thought that judges "found" rather than "made" common law.

Second, it is not clear why the antitrust statutes are supposed to be exceptional. The statutes sometimes are vague or use legal terms of art, but that is true of many, perhaps most statutes. And if it is possible to find stray statements in the legislative history expressing the expectation that the courts will clarify ambiguities, that too must be typical of the legislative history of a great many statutes. How often, one wonders, do the supporters of a bill dodge hard questions about its application by expressing confidence in the wisdom of the courts? If the Sherman Act is a delegation of lawmaking power, so too are a great many laws. If this is what textualists mean, they should admit that textualism would greatly expand judicial discretion in a broad range of cases. ${ }^{160}$

One might argue that the antitrust laws are special because antitrust texts simply provide no specificity at all, communicating only that Congress wanted the courts to do something about monopolies and competition. But that conclusion finds such ready acceptance, we think,

159. Business Electronics Corp. v. Sharp Electronics Corp., 485 U.S. 717, 735-36 (1988).

160. A somewhat similar delegation argument has been used to justify the Chevron doctrine of deference to administrative agencies. See Thomas Merrill \& Kristin Hickman, Chevron's Domain, 89 GEO. L.J. 833, 870-872 (2001) (viewing this as the best explanation of the doctrine even though the "delegation" is a legal fiction). But the Chevron analogy would sweep far beyond the antitrust laws. It suggests that whenever a statute is ambiguous, courts are free to make their own policy judgments rather than choosing the explanation that best fits text and precedent. Perhaps some textualists do mean to endorse such broad judicial activism, but if so, their arguments about limiting judicial discretion are, to say the least, puzzling. In any event, the very basis of Chevron is the argument that agencies are more politically accountable than courts, so it hardly makes sense to use Chevron as an argument for giving judges the same powers as agencies. 
only because it is self-fulfilling: expecting to find no guidance in the text, no one bothers looking. As we saw in part III, for a textualist who takes statutory language seriously as the main source of interpretation, there is plenty of guidance to be found.

A related argument is that the statutory text seems to apply universally, leaving the courts no choice but to devise their own limitations. ${ }^{161}$ Early in the semester, antitrust teachers not uncommonly point out that every contract "restrains trade" in the sense of committing the parties to make a trade with each other even if they might later prefer to trade with someone else. Thus, students conclude, the statutory reference to contracts in restraint of trade cannot mean what it says and can be safely disregarded in analyzing cases. This is, in part, a variety of the absurdity doctrine, which at least some textualists reject. ${ }^{162}$ In any event, it is an argument that no textualist should take seriously. "Contract in restraint of trade" may seem unlimited if it is taken as ordinary English, but it was in fact a legal term of art and had a well-established meaning.

To see how far this approach to antitrust is from that normally taken by textualists, we need only contrast it with that taken by textualists in Sweet Home and Gottshall. Imagine an antitrust-style opinion by Justice Scalia in Sweet Home, where the question was whether habitat destruction could qualify as a "take" under the Endangered Species Act. Rather than stressing the firmly established legal meaning of the term "term" in wildlife law, Justice Scalia's conclusion would have been something more like the following: "in short, ecological analysis supports the ban on habitat modification, and none of our precedents is to the contrary." Or imagine a similar decision by Justice Thomas in Gottshall, ignoring the common law developments in the state courts in favor of an economic analysis of tort liability for mental distress. Such an analysis is not out of the question, and a few judges-most notably Posner - might approach Gottshall this way. But no one has ever confused Posner's views of the judicial function with textualism! The fact that the conventional wisdom of textualists about antitrust laws converges with Posnerian anti-textualism ought to make textualists very nervous.

Among the commonly accepted arguments for textualism is that it keeps federal judges in their proper role-interpreting law rather than making it-and that it keeps Congress honest by making it face hard questions rather than hoping the courts will save the day. Both of these rationales argue against reading statutes as delegations of lawmaking authority to courts.

161. See Baxter, supra note 153, at 664 .

162. See Manning, supra note 46, for an extended argument that the absurdity doctrine is inconsistent with textualism. 
True, there are examples where Congress has delegated "legislative" authority to courts, as when it authorized the Court to issue the federal rules of civil procedure. But we can hardly imagine Congress passing a bill to authorize the Supreme Court to issue the "Federal Rules of Antitrust." Nor do the statutes express such an intention in other terms, such as a naked jurisdictional grant unaccompanied by any statement of substantive legal rules.

The delegation theory is especially unpalatable because the antitrust laws from the beginning have involved criminal penalties. Early in our history, the Supreme Court held that there is no federal common law of crimes. It is unclear whether Congress could authorize the courts to create such common law crimes; at least some might think this an unconstitutional delegation of legislative authority. Surely we should not presume, without the clearest of supporting evidence, that Congress intended to give criminal lawmaking authority to the federal courts, even within a specific sphere such as competition law.

These arguments do not disprove, even for textualists, the idea that the antitrust statutes left room for judicial development. But the delegation argument says a lot more than this. It says that this judicial development is essentially unrestrained by the normal tools of statutory interpretation or the normal processes of the common law system. Instead, the delegation argument directs judges to impose their own views of public policy, free from constraint. ${ }^{163}$ Surely textualists, of all people, should be among the last to embrace such a view of the judicial function.

The grain of truth in the delegation argument is that, when other sources of interpretation run out, courts must fall back on a common law process of legal elaboration. But the delegation argument goes wrong in two places. It wrongly assumes that the other sources of interpretation run out almost from the beginning where the antitrust laws are concerned. For textualists, at least, this is not necessarily so. And the argument also goes wrong by confusing the common law process with the raw pursuit of policy outcomes. Even if this characterization were more accurate, it should lead textualists to eschew the delegation doctrine except as an absolute last resort, when no meaning at all can be extracted from the statutory text itself.

Perhaps the ultimate fallback position for textualists who like current antitrust doctrine would be that, even if the delegation is wrong as a

163. On the possibility that economics could provide the needed constraint, see infra note 170-72 and accompanying text. 
matter of original textual meaning, it is too well-entrenched in precedent to be displaced today. The question of how textualists should deal with "incorrect" precedents is a vexing one, and not one that we would attempt to resolve here. ${ }^{164}$ Some antitrust precedents may be too entrenched to overrule now, even if they are erroneous as a matter of textual interpretation. Yet textualists should be cautious about resorting to stare decisis as a defense for antitrust rulings they find indefensible in principle. In other settings, textualists have not shown themselves reluctant to reject wellentrenched understandings on occasion.

A notable example is Justice Thomas's concurrence in Holder $v$. Hall, ${ }^{165}$ a striking opinion rejecting foundational statutory precedent. The question in Holder was whether section 2 of the Voting Rights Act prohibited the use of a single commissioner form of municipal government, where the effect of using a single commissioner was to ensure election of the candidate preferred by white voters. In his concurrence, Justice Thomas argued that the Voting Rights Act lacks any application to redistricting decisions, an argument at odds with the general understanding of judges and practitioners in the area. The statute governs any voting "standard, practice, or procedure," and Justice Thomas argued that districting does not fall within the ordinary meaning of any of these terms. ${ }^{166}$ Justice Ginsburg's dissenting opinion points out the challenges that Justice Thomas was willing to surmount to reach this conclusion: (1) similar language in section 5 of the statute had been construed to the contrary in a host of Supreme Court decisions, and Thomas did not squarely attack that interpretation; (2) when Congress amended section 2 in 1982 to adopt an effects test, it was responding to a Supreme Court decision applying an intent test to redistricting, and the legislative history makes it unmistakable that the amendment was adopted to deal with racial vote dilution in redistricting; and (3) the Court had previously held squarely against Thomas's interpretation in construing section 2 itself. ${ }^{167}$

In addition to reliance on plain language, Justice Thomas's opinion also stressed that the Court was forced to resort to political theory rather than purely legal sources in resolving vote dilution disputes. Justice Ginsburg's response is quite apropos to the topic at hand: "Statutes frequently require courts to make policy decisions. The Sherman Act,

164. For reflections by a leading textualist on the subject, see Frank Easterbrook, Stability and Reliability in Judicial Decisions, 73 CORNELL L. REV. 422 (1988).

165. 512 U.S. 874 (1994).

166. Holder, 512 U.S. at 891 (Thomas, J., concurring in the judgment).

167. Holder, 512 U.S. 956-65 (Ginsburg, J. dissenting). Ginsburg was not, however, in dissent on this particular point, since five Justices rejected Thomas's interpretation of section 2 to exclude districting. 
for example, requires courts to delve deeply into the theory of economic organization." 168 Reversing the comparison, one might suggest that if Justice Thomas is correct that it is inappropriate for courts to make decisions based on non-legal analysis under the VRA, precedent notwithstanding, then it might be equally inappropriate to do so under the antitrust laws.

The greater undesirability of judicial intrusion into the political arena, the arguably less settled status of voting theory as opposed to economic theory, plus the shorter history of the VRA, may combine to make Holder distinguishable, though it is not clear that textualists ought to be eager to embrace these distinctions. But even if textualists feel unable to overrule existing antitrust precedents adopting non-legal analyses, that should probably be no reason to extend the erroneous reasoning of those precedents into other areas. Some earlier antitrust judges may have mistaken their role in statutory interpretation for economic policymaking. Yet the whole point of textualism is to correct an even more deeply entrenched judicial error (reliance on statutory purpose and legislative history).

Another argument in favor of current antitrust interpretation could be Congressional acquiescence. Courts have been treating the antitrust statutes as a mere starting point for common law decisionmaking for a long time now. Congress must be aware of this judicial practice, and if it is unhappy with the approach the courts have taken, it could always revise the antitrust laws to provide more specificity, but for the most part it has not done so. This is not an implausible argument, but it is not an argument that is available to textualists. Courts sometimes do accept such Congressional acquiescence arguments, but that move is not legitimate within a textualist approach. In the words of Justice Scalia, "vindication by Congressional inaction is a canard."169 If the antitrust statutes have genuine meaning, courts are not authorized to amend the statutes through interpretation, nor can Congress amend statutes by the simple device of allowing the courts to do so. Or in any event, that is what textualism stands for.

Far more judges in recent decades have, from a textualist perspective, mistaken their role in statutory interpretation as a search for original intent as found in legislative history, than have used microeconomics to control antitrust analysis. Textualists are forthright in rejecting what they

168. Id. at 966 .

169. Johnson v. Transportation Agency, Santa Clara County, 480 U.S. 616, 672 (Scalia, J., dissenting). 
consider the intentionalist fallacy as a means for deciding new issues of interpretation, whatever the status of past erroneous holdings. If precedent is not enough to hallow the use of legislative history, it should not be enough to entrench a purely policy-oriented approach to antitrust. Consequently, textualists should disown the delegation fallacy in deciding new antitrust issues.

But even if textualists believe that it is too late to unscramble these particular eggs, they should not flinch from correctly describing the situation. From a textualist point of view, much of current antitrust analysis is wrong in principle, and that fact should be acknowledged even if a cure is no longer practical.

\section{B. Broader Implications}

It is understandable that textualists have tried to submerge the tension between their general theories of statutory interpretation and their approach to the antitrust laws. Antitrust doctrine is often regarded as the epitome of sophisticated statutory implementation by judges, and the current Chicago-oriented approach is probably ideologically congenial to many textualists. Thus, textualists cannot be blamed for wanting to exempt antitrust from their general theory of interpretation. But this form of antitrust exceptionalism simply will not wash. In the end, the antitrust statutes are different from other laws only in degree, if at all, in the extent to which determinate meaning can be extracted from the statutory language.

Those who accept our argument to this point can choose among three basic alternative conclusions. First, reject textualism and accept the reigning approach to antitrust, heavily policy-driven with economics as the guide for judges. Second, accept textualism and advocate a new, textualist approach to the antitrust statutes. Third, reject both textualisin and the reigning approach to antitrust. What one cannot do is accept both textualism and modern antitrust interpretation. We sketch out the three available alternatives in this section.

First, one could take our arguments in section III as illustrating the folly of applying textualisin to the antitrust statutes (or any other statutes, for that matter). For one thing, many may believe, antitrust textualism will lead to results that make society worse off. The Holmes approach to the Sherman Act fails to prohibit much behavior that we now see as central to the concerns of antitrust. Ignoring an efficiency defense and more wooden readings of the tying and price discrimination provisions will prohibit much economically beneficial behavior.

Moreover, textualism alone will fail to answer many of the key questions courts face. For instance, even supposing one accepts our 
argument as to the efficiency defense in mergers, many other questions arise in interpreting section 7 of the Clayton Act. How does one define the relevant markets in which a firm competes? How does one tell how competitive a market currently is, and how competitive it will be if the merger occurs? How much of a reduction in competition is enough to qualify as a substantial lessening? The statutory language, even interpreted using sophisticated textual tools, can probably provide only broad constraints on the answers to these questions. Courts recognized those constraints long ago. All of the action on these issues today occurs within those broad bounds of the text, and textualism has little to offer there.

The second possible conclusion affirms textualism. One can question whether telling judges to choose efficient rules according to the maxims of economics has really had such fine consequences. For one thing, economists tend to disagree with one another. A lot. The early advocates of an economic approach to antitrust, e.g. Robert Bork ${ }^{170}$ and Richard Posner, ${ }^{171}$ espoused a laissez-faire, price theory-based understanding of economics. Many more recent industrial organization economists, drawing upon game theory and the economics of information, have been more inclined to find market imperfections and to believe that judicial intervention can frequently improve welfare. ${ }^{172}$ For another thing, even if economists could agree on their analysis, one can question how good judges would be at understanding and following that analysis. Limiting the discretion of judges to legislate in an area that they do not understand may make sense.

Even if one believes that the current approach to antitrust does generally tend to lead to happy results, the democratic argument for textualism still applies. Even those not firmly committed to textualism may be uncomfortable at how readily the Justices bypass statutory language that Congress enacted on their way to imposing their own ideas of the best policy. The modern approach to antitrust vests the kind of legislative power in courts that a democracy usually reserves either for legislatures or for executive agencies, both politically more accountable

170. ROBERT BORK, THE ANTITRUST PARADOX: A POLICY AT WAR WITH ITSELF (1978).

171. See POSNER, supra note 104.

172. See F.M. Scherer, Some Principles for Post-Chicago Antitrust Analysis, 52 CASE W. Res. L. Rev. 5 (2001); Timothy J. Brennan, Do Easy Cases Make Bad Law? Antitrust Innovation or Missed Opportunities in United States v. Microsoft, 69 GEO. WASH. L. REV. 1042 (2001); Michael S. Jacobs, An Essay on the Normative Foundations of Antitrust Economics, 74 N.C. L. REV. 219 (1995); Symposium, Post-Chicago Economics, 63 ANTITRUST L.J. 445 (1995). 
than unelected federal judges. ${ }^{173}$ It is one thing to engage in dynamic interpretation of the words of a statute, another thing to ignore those words altogether.

The criticism that textualism will fail to fully answer many questions may be overblown as well. First, setting broad limits to the appropriate answers may itself be an important function. Second, deference to FTC interpretations of the statute could go a long way filling out many remaining textual ambiguities. Thus, in interpreting section 7 of the Clayton Act, the Merger Guidelines and specific FTC decisions can fill out much of the interpretive space that the statutory text leaves open. ${ }^{174}$

The third and final possible response to our arguments is to say a plague on both your houses: reject both textualism and the current approach to antitrust statutory interpretation. This response takes as a starting point the criticisms made in each of the prior two responses. Textualism applied too single-mindedly may sometimes lead to quite bad consequences, and in many other cases will not give enough guidance to answer questions that courts face. On the other hand, interpreting the antitrust statutes as simply directing judges to go forth and commit economics may not lead to much better results and is quite undemocratic.

To avoid antitrust nihilism, someone choosing this path must advocate a third way in antitrust statutory interpretation. Two possibilities suggest themselves. The first is a purposivist approach. Purposivism is a second great general approach to statutory interpretation. ${ }^{175}$ It focuses on the broad goals of a statute, on the problem the legislatures meant to address through passing the statute. Both the text and the legislative history help a court determine those goals. Faced with the question of how to decide a case, the courts first strive to-ascertain a statute's goals and then ask what resolution of the case would best help advance those goals. Where several statutes apply, a purposivist will try to treat the statutes as a whole, with a common purpose, to the extent possible.

Proponents of the Chicago approach to antitrust will not be pleased with this alternative. Robert Bork's early interpretation of the legislative history of the antitrust statutes as focused mainly on advancing economic efficiency now looks quite suspect. Instead, fear of big business and

173. See Scalia, supra note 1, at 9-14.

174. See supra note 144 and accompanying text. Of course, courts must decide what space the statutory language leaves open-that is the first step of the Chevron twostep. Strong textualists might believe that in many cases the antitrust statutes alone answer the question. But here we are concerned with cases where the court cannot find an answer in the text. In that case, they can look to agency interpretation, if available, and follow that interpretation so long as it is not unreasonable - the second part of the Chevron two-step.

175. See ESKRIDGE ET AL., supra note 9, at 670. 
support for small business, distributive concerns, and concern for the corruption of politics by corporations were all also important influences in creating the antitrust statutes. ${ }^{176}$ Many Warren Court antitrust cases ${ }^{177}$ probably give a pretty good sense of what a purposivist approach to antitrust statutory interpretation would look like.

The other possibility is a pragmatic approach to statutory interpretation. This approach borrows from all of the other approaches, trying to analyze a case from a variety of perspectives and reach a decision that a court can support using a number of different types of arguments. ${ }^{178}$ Analysis would begin with the statutory text, and insofar as textualist arguments can point to a relatively clear decision, would end there absent compelling considerations of another type. If the text does not provide a clear answer, the pragmatist looks to legislative history and purpose for further help. Agency interpretation, if available, may be dispositive, or at least helpful. To the extent that no clear answer emerges from any of these sources, the pragmatist also considers what decision would best advance current values. Those values need not only be efficiency, though; distributive fairness may also be important, for instance. ${ }^{179}$ Note that this approach need not degenerate into messy multi-factor balancing. In many areas, the courts may decide that statutory language, or statutory language and purpose combined, dictate a per se rule of legality or illegality. Indeed, we would expect that a pragmatic approach would be more likely to use per se rules than the current economics-based approach, which quite frequently relies on the rule of reason. Furthermore, a pragmatist approach would probably give more weight than the current approach to the views of the FTC in shaping antitrust rules.

In this paper we remain agnostic as to what conclusion is best. We only assert that advocating textualism and supporting the reigning

176. See Robert H. Lande, Wealth Transfer as the Original and Primary Concern of Antitrust: The Efficiency Interpretation Challenged, 50 HASTINGS L.J. 871 (1999).

177. See, e.g., United States v. Von's Grocery Co., 384 U.S. 270 (1966); Brown Shoe Co. v. United States, 370 U.S. 294 (1962); Utah Pie v. Continental Baking Co., 386 U.S. 685 (1967).

178. See William Eskridge, Jr. \& Philip Frickey, Statutory Interpretation as Practical Reasoning, 42 STAN. L. REV. 321 (1990).

179. See Robert H. Lande, Wealth Transfers as the Original and Primary Concern of Antitrust: The Efficiency Interpretation Challenged, 50 HaSTINGS L.J. 871 (1999); Daniel A. Farber \& Brett H. McDonnell, Why (and How) Fairness Matters at the IP/Antitrust Interface, 87 MINN. L. REV. 1817 (2003). 
approach to interpreting the antitrust statutes are inconsistent positions. Deciding among the competing conclusions one can draw from that observation would require a detailed inquiry into both antitrust law and the theory of statutory interpretation, an inquiry whose detail goes far beyond the bounds of this paper.

\section{CONCLUSION}

Many scholars and judges today believe that the antitrust statutes are essentially devoid of content. They respond with an aggressively dynamic approach in which courts reach the results that they believe will best advance consumer welfare according to their understanding of economics and business practices. Most remarkably, even leading advocates of textualism such as Justice Scalia and Judge Easterbrook advocate this approach to the antitrust statutes.

We have argued that those statutes are not so content-free as all that. The Sherman Act could have been given more specific content by reference to pre-existing common law. The Clayton and RobinsonPatman Acts are even more specific. The one act that truly delegates broad discretionary authority is the Federal Trade Commission Act, but it delegates that authority to the FTC, not the courts.

We thus suggest that textualism and the contemporary approach to interpreting the antitrust statutes are incompatible. In response, one can reject textualism, reject the reigning approach to the antitrust states, or reject both. What one cannot do is accept both textualism and modern antitrust statutory interpretation. 